\title{
Development of Polymer-Based Nanoformulations for Glioblastoma Brain Cancer Therapy and Diagnosis: An Update
}

\author{
Bijuli Rabha ${ }^{1,+}{ }^{\dagger}$ Kaushik Kumar Bharadwaj ${ }^{1,+} \oplus$, Siddhartha Pati ${ }^{2,3,+}{ }^{-}$, Bhabesh Kumar Choudhury ${ }^{4}(\mathbb{D}$, \\ Tanmay Sarkar ${ }^{5,6}{ }^{\oplus}$, Zulhisyam Abdul Kari ${ }^{7}{ }^{\oplus}$, Hisham Atan Edinur ${ }^{8}{ }^{\circ}$, Debabrat Baishya ${ }^{1, *} \mathbb{C}$ \\ and Leonard Ionut Atanase $9, *$ (D)
}

check for updates

Citation: Rabha, B.; Bharadwaj, K.K.; Pati, S.; Choudhury, B.K.; Sarkar, T.; Kari, Z.A.; Edinur, H.A.; Baishya, D.; Atanase, L.I. Development of Polymer-Based Nanoformulations for Glioblastoma Brain Cancer Therapy and Diagnosis: An Update. Polymers 2021, 13, 4114. https://doi.org/ $10.3390 /$ polym 13234114

Academic Editor: Ki Hyun Bae

Received: 31 October 2021

Accepted: 24 November 2021

Published: 26 November 2021

Publisher's Note: MDPI stays neutra with regard to jurisdictional claims in published maps and institutional affiliations.

Copyright: (c) 2021 by the authors Licensee MDPI, Basel, Switzerland. This article is an open access article distributed under the terms and conditions of the Creative Commons Attribution (CC BY) license (https:// creativecommons.org/licenses/by/ $4.0 /)$
1 Department of Bioengineering \& Technology, GUIST, Gauhati University, Guwahati 781014, India; bijulipep@gmail.com (B.R.); kkbhrdwj01@gmail.com (K.K.B.)

2 Skills Innovation \& Academic Network (SIAN) Institute-Association for Biodiversity Conservation and Research (ABC), Balasore 756001, India; patisiddhartha@gmail.com

3 NatNov Bioscience Private Limited, Balasore 756001, India

4 Department of Chemistry, Gauhati University, Guwahati 781014, India; bkcsat@gmail.com

5 Malda Polytechnic, West Bengal State Council of Technical Education, Govt. of West Bengal, Malda 732102, India; tanmays468@gmail.com

6 Department of Food Technology and Biochemical Engineering, Jadavpur University, Kolkata 700032, India

7 Faculty of Agro Based Industry, Universiti Malaysia Kelantan, Jeli 17600, Malaysia; zulhisyam.a@umk.edu.my

8 School of Health Sciences, Health Campus, Universiti Sains Malaysia, Kubang Kerian 16150, Malaysia; edinur@usm.my

9 Faculty of Medical Dentistry, "Apollonia" University of Iasi, 700511 Iasi, Romania

* Correspondence: drdbaishya@gmail.com (D.B.); leonard.atanase@yahoo.com (L.I.A.)

+ Marked authors contributed equally.

Abstract: Brain cancers, mainly high-grade gliomas/glioblastoma, are characterized by uncontrolled proliferation and recurrence with an extremely poor prognosis. Despite various conventional treatment strategies, viz., resection, chemotherapy, and radiotherapy, the outcomes are still inefficient against glioblastoma. The blood-brain barrier is one of the major issues that affect the effective delivery of drugs to the brain for glioblastoma therapy. Various studies have been undergone in order to find novel therapeutic strategies for effective glioblastoma treatment. The advent of nanodiagnostics, i.e., imaging combined with therapies termed as nanotheranostics, can improve the therapeutic efficacy by determining the extent of tumour distribution prior to surgery as well as the response to a treatment regimen after surgery. Polymer nanoparticles gain tremendous attention due to their versatile nature for modification that allows precise targeting, diagnosis, and drug delivery to the brain with minimal adverse side effects. This review addresses the advancements of polymer nanoparticles in drug delivery, diagnosis, and therapy against brain cancer. The mechanisms of drug delivery to the brain of these systems and their future directions are also briefly discussed.

Keywords: polymer nanoparticles; glioma/glioblastoma; blood-brain barrier (BBB)/blood brain tumour barrier (BBTB); nanodiagnostics; drug delivery and imaging

\section{Introduction}

Cancer is one of the serious life-threatening diseases worldwide with a higher risk of mortality, around 10 million new cases are diagnosed every year [1,2]. Among different types of cancer, brain cancer is the most lethal and invasive type of central nervous system (CNS) disorder [3]. Brain cancer is characterised as a heterogeneous group of primary and metastatic cancers in the CNS [4,5]. The average incidence of both malignant and nonmalignant brain cancer is reported approximately 28.57 per 100,000 population, mostly affecting 0 to 19 years, with a mean annual morbidity rate of 5.57 per 100,000 population [6,7]. Among these, the malignant primary brain cancers with a 5-year survival rate of less than $33.3-35 \%$ and even the rate are still alleviating. The average survival span is still not 
improved and even lower between 15 to 22 months [8,9]. A recent report from 2020 of the Central Brain Tumor Registry of the United States accounted for primary malignant tumour incidence rate to be 7.08 per 100,000, with 123,484 estimated cases, and 16.71 per 100,000 , with 291,927 cases of non-malignant tumour [10]. Malignant primary tumours, i.e., gliomas derived from the glial origin, are newly diagnosed for approximately $70 \%$, mostly in adults $[5,11]$. The reduced efficacy of brain cancer therapy is mainly attributed to the presence of the blood-brain barrier (BBB) that limits the permeation of systemically applied drugs into the brain [3].

Brain cancers are categorised into two groups, viz., primary brain cancer originated from the brain and resided within the brain, commonly called glioma, and secondary or metastatic brain cancer spreading from primary cancer outside the CNS, originate from systemic neoplasms and further evolved in the interior of brain parenchyma [12,13]. Glial cell originated gliomas include glioblastomas, astrocytomas, schwannomas, oligodendrogliomas, etc. [14]. According to World Health Organization (WHO), glioma tumours of CNS is classified into four grades based on aggressiveness, Grade I pilocytic astrocytoma, Grade II diffuse astrocytoma, Grade III anaplastic astrocytoma, and Grade IV glioblastoma [12]. Glioblastoma (GBM) and its variants were categorised as Grade IV tumours [15]. Grades I and II are considered low-grade glioma, and Grades III and IV are considered high-grade gliomas, i.e., malignant gliomas, and are characterised by poor prognosis $[8,16,17]$. GBM can either develop from normal brain cells or evolve from preexisting low-grade astrocytoma [18]. GBM is also termed as glioblastoma multiforme or Grade IV astrocytoma [19]. Excessive penetration and vascular proliferation into brain parenchyma is the indication of aggressive cancer [20].

Conventional glioma therapy includes tumour resection followed by radiotherapy and chemotherapy. Surgical resection is generally considered a standard method for glioblastoma therapy. Yet resection of tumour tissue cannot be entirely removed and hence is limited by the glioblastoma's aggressiveness caused by penetration into surrounding tissue microenvironment and tumour vascularisation [20,21]. Hence, tumour resection is associated with the administration of chemotherapeutic drugs and/or radiation therapy for enhanced efficiency. Radiation therapy can be delivered internally or externally and is regarded as the standard treatment for high-grade gliomas [22]. Chemotherapy drugs such as carmustine (BCNU) can cross the BBB and target glioma cells directly [20]. Further, chemotherapy has undergone some alteration by replacing the use of some alkylating agents, viz., carmustine (BCNU), nimustine (ACNU), and lomustine (CCNU) with temozolomide (TMZ) [23]. Temozolomide is converted to 5-3-(methyl)-1-(triazen-1-yl) imidazole-4-carboxamide, at physiological $\mathrm{pH}$, damages DNA via methylation of the O6position of guanines, blocks DNA replication and induces tumour cell death. Presently, TMZ, along with surgical resection and radiotherapy, is applied for glioblastoma therapy [17]. Despite that, all the treatment strategies possess some limitations towards survival and thus, the prognosis still remains poor (Table 1).

Although brain cancer resembles to other forms of cancer in the body, the major difference is their intracranial neoplasms, heterogeneity, intricate brain system, and the physiological features of the cranial cavity which restrain the treatment options [10]. Gliomas tend to permeate the surrounding tissue microenvironment, and thereby, it is very difficult to determine the tumour boundaries. This also attributes to several difficulties in conventional therapeutic approaches for a curative outcome. Moreover, the physical and chemical barriers hamper therapeutic drug molecules from reaching tumour locations [11]. The BBB and blood-brain tumour barrier (BBTB) represent the diffusion barrier systems of the brain that regulate the influx of drugs to the brain except owing to certain characteristics [24]. Standard treatments remain ineffective due to poor surgical resection of tumours, mainly the infiltrative ones, poor chemo-therapeutic drug influx to the tumour site, and BBB that restrict them from diffusing toward tumour location [25]. The limitations of radiotherapy also result in incomplete eradication of GBM cells resulting in self-renewal and recurrence [26]. Targeting active anticancer agents to the brain is a challenging task in 
the area of drug delivery as BBB prevents the transportation of a drug. Hence, higher doses are needed to attain desired therapeutic efficacy which causes undesirable side effects [27].

Table 1. Advantages and limitations of conventional glioblastoma therapy.

\begin{tabular}{|c|c|c|}
\hline Conventional Therapy & Advantage & Limitation \\
\hline Resection & $\begin{array}{l}\text { Local removal of } \\
\text { a tumour }\end{array}$ & $\begin{array}{l}\text { - } \quad \text { Entire tumour cannot be removed } \\
\text { relapse within } 2 \text { to } 3 \mathrm{~cm} \text { of the } \\
\text { original tumour boundary } \\
\text { - } \quad \text { Invasive in nature }\end{array}$ \\
\hline Radiotherapy & $\begin{array}{l}\text { Standard treatment } \\
\text { protocol for HGGs }\end{array}$ & $\begin{array}{ll}\text { - } & \text { Necrosis of normal brain tissue } \\
\text { - } & \text { Neuronal damage } \\
& \text { Resistance to radiation of tumour cells }\end{array}$ \\
\hline Chemotherapy & $\begin{array}{l}\text { Standard therapy for } \\
\text { cancer, cytotoxicity }\end{array}$ & $\begin{array}{ll}\text { - } & \text { High dose } \\
\text { - } & \text { BBB } \\
\text { - } & \text { Low accumulation of the drug } \\
\text { - } & \text { Resistance to drug }\end{array}$ \\
\hline
\end{tabular}

\section{The Blood-Brain Barrier (BBB)}

One of the main hurdles for the effective systemic treatment of brain cancer is the presence of the BBB. The BBB is a semipermeable membrane barrier between blood capillaries and cellular components of brain tissues that control the movement of ions, nutrients, and cells. The BBB also serves for the dynamic transport of nutrients, peptides, proteins and immune cells between the brain and blood [28]. The BBB consists of endothelial cells, glial cells (pericytes, astrocytes, and neurons) and basement membrane [29] (Figure 1). The endothelial cells line the interior brain capillaries forming the tight junctions that allow small molecules, gases and curb the influx of harmful toxins or pathogens such as bacteria, lipophilic neurotoxins, xenobiotics and hydrophilic substances from the blood to the brain [30]. Due to the presence of pinocytic vesicles, other carriers, transport proteins, and large numbers of mitochondria, hydrophobic and essential molecules such as $\mathrm{O}_{2}$, $\mathrm{CO}_{2}$, glucose, hormones, etc. can infiltrate either by passive diffusion or active transport mechanisms [29]. The presence of several transmembrane proteins characterises the tight junctions between the inter-endothelial cells. These protein complexes are mainly comprised of occludin, claudin, and junctional adhesion molecules. These three specialised proteins interact to develop an intricate, tight barrier that is exclusive to the cerebroendothelial cells [31]. The apical part of the endothelial cell is exposed to the brain's blood capillaries, and the basolateral part is exposed to the cerebrospinal fluid supported by the basement membrane. The basement membrane with 30-40 nm thickness consists of Type IV collagen, fibronectin, laminin, heparin sulfate proteoglycans and other extracellular matrix proteins that completely covers the endothelial cells and limits the movement of the solutes [29,31,32]. Approximately $98 \%$ of smaller molecular weight drugs and $100 \%$ of larger molecular weight drugs are reported for their inability to cross the intact BBB $[33,34]$. Under various brain-related pathological conditions, including brain cancers, glioma cells loose the structural integrity and the function of the BBB [35]. BBB is compromised in human glioma cells because of the leaky inter endothelial tight junction and poorly differentiated astrocytes that are unable to release essential components for BBB function $[31,36]$. In this case, it is termed as blood-brain tumour barrier (BBTB) or blood-tumour barrier (BTB) [14] (Figure 1). 


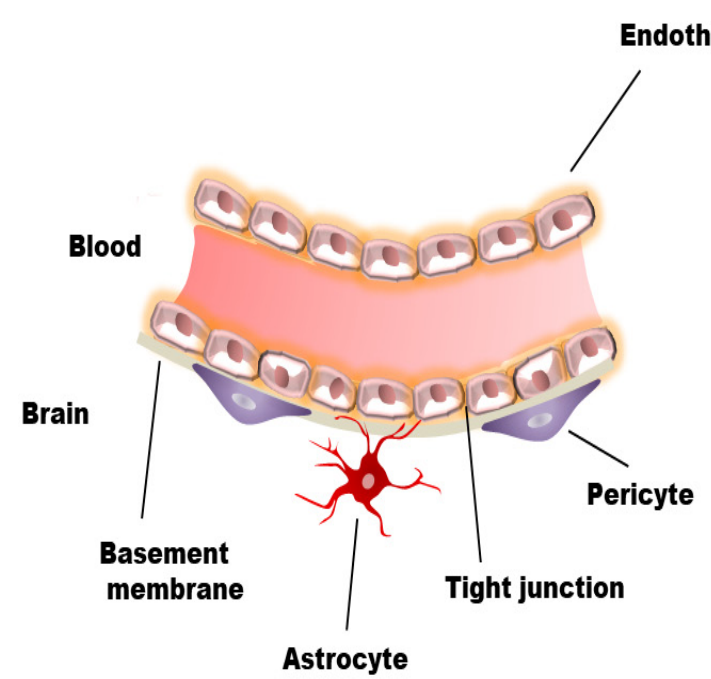

Blood Brain Barrier (BBB)

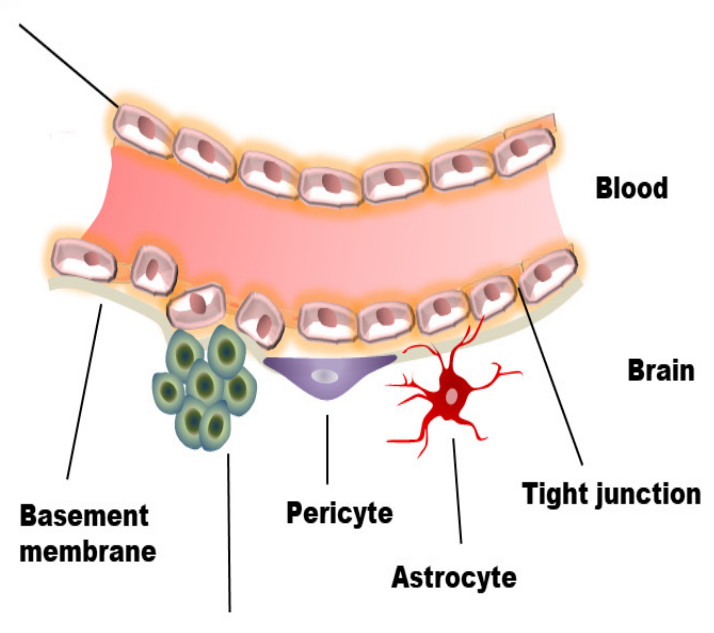

Tumor tissue

Figure 1. Schematic representation of blood-brain Barrier (BBB) and the blood-brain tumour barrier (BBTB).

In low-grade gliomas, the structure and function of the BBTB resemble normal BBB, while in hi-grade glioma, $B B B$ is significantly altered, disrupted. Although the degree of BBB disruption varies from the tumour malignancy, low-grade glioma is still a hurdle to treat due to intact BBB. Despite high-grade gliomas, the structural disruption of their vascular density and integrity is negligible to drug permeability in tumour cells $[37,38]$. However, BBTB is more permeable than the BBB and allows heterogeneous permeability to drugs and other components. Thus, it is a more challenging task to combat the difficulties of brain cancer [39]. Therefore, along with the existing therapeutic regimen, new approaches are required to combat the BBB. To combat these difficulties, various techniques were developed, which are mostly invasive and cause serious side effects. Nanotechnology, especially use of polymer nanoparticles, helps address the major hurdle of glioma therapy non-invasively. Polymer nanoparticles aid in the targeting and delivery of potent drug molecules to the brain. In this review paper, we will briefly summarise the up-to-date existing therapies and diagnoses in brain cancer gliomas using polymer nanoparticles.

\section{Polymer Nanoparticles for Drug Delivery Strategy to Overcome the BBB}

The BBB is the main problem in the treatment of brain cancer glioma. The chemotherapeutic drugs are mostly ineffective due to limiting permeability to BBB as it allows to pass only low molecular weight $(<500 \mathrm{Da})$, electrically neutral hydrophobic drugs with lipophilicity at $\log$ P 2-3 [11,36,40]. The majority of chemotherapeutic drugs are larger in size, ionic, hydrophilic molecules and thus cannot cross the BBB that is attributed to the requirement of a higher systemic dose that results in severe side effects [11]. To overcome these drawbacks, nanoparticles can be utilised for the controlled and sustained delivery of drugs. Biodegradable polymer nanoparticles are extensively studied systems in cancer drug delivery and therapy. These nanoparticles are also highly stable and can be tuned in order to obtain the desirable characteristics for a passive or an active targeting [41]. Polymer nanoparticles can induce selective toxicity and can load ample anticancer drugs or other molecules. Various biodegradable polymeric drug delivery systems include nanogels or hydrogels, poly( $\varepsilon$-caprolactone) (PCL), poly (lactic-co-glycolic acid) (PLGA), chitosan [42,43], dendrimers, etc. [44]. Due to versatile tuneable properties, these nanoparticles can open tight junctions of $\mathrm{BBB}$, shield $\mathrm{BBB}$ limiting properties of anticancer drugs, release the drug 
in a sustainable manner, prolong the systemic circulation, and protect against enzymatic degradation $[1,45]$.

Studies showed that Resveratrol loaded PLGA: D- $\alpha$-tocopheryl polyethylene glycol 1000 succinate blend nanoparticles (RSV-PLGA-BNPs) displayed significant increasing cytotoxicity and enhanced cell penetration in C6 glioma cells. Haemocompatibility evaluation is one of the critical analyses of interaction between nanoparticles and various blood components that determine any adverse effect upon nanoparticle exposure to blood. The nanoparticles should not cause haemolysis during and after infusions. The haemocompatibility analysis of RSV-PLGA-BNPs revealed safe for i.v. administration. The nanoparticles exhibited prolonged systemic circulation up to $36 \mathrm{~h}$. The nanoparticles also showed higher brain accumulation, suggesting a potential system for the betterment of systemic circulation and plasma half-life with a promising anticancer effect against glioma [1]. In another study, L-carnitine-conjugated PLGA NPs were developed to target glioma cells. These NPs were found to significantly cross the BBB and showed a potential anti-glioma effect [46]. Lactoferrin decorated PEG-PLGA NPs was developed for the delivery of shikonin and the treatment of gliomas [47]. Lactoferrin coating promotes internalisation across the BBB. In vitro and in vivo experiments showed the enhanced nanoparticle uptake and distribution of NPs in the brain with effective treatment of glioblastomas.

\section{Polymer Nanoparticles for Anticancer Drug Delivery to the Brain: Mechanism}

Polymer nanoparticles can cross BBB or BBTB either passively or via active endocytosis mechanisms. The unmodified polymer NPs internalise BBB mainly through passive mechanism, the so-called enhanced permeability and retention (EPR) effect, which depends on nanoparticle size. However, the NPS internalised by a passive mechanism have comparatively lower brain uptake than ligand-functionalised polymer NPs [48]. Various strategies have been undertaken to improve the infiltration of NPs into the brain. These strategies involve modification of NPs with certain moieties or components to take benefit of BBB endocytosis pathways for drug delivery. Polymer nanoparticles are able to cross $\mathrm{BBB} / \mathrm{BBTB}$ through adsorption-mediated transcytosis (AMT), carrier-mediated transport (CMT), and receptor-mediated transcytosis (RMT) [49-52] (Figure 2). The internalisation of polymer nanoparticles crossing BBB/BBTB is summarized in Table 2. Polymer nanoparticles with positively charged can electrostatically interact with a negatively charged luminal surface that is attributed to cross the BBB/BBTB. The cationic polymer nanoparticles can be achieved by various surface modification strategies, either by coating or conjugation of cationic polymer or surfactant to non-ionic or neutral polymer. These modifications of NPs have been shown to utilise the AMT mechanisms to improve brain uptake. For example, a study of cationic bovine serum albumin (CBSA) conjugated with poly (ethylene glycol)-b-poly(lactide) (PEG-PLA) nanoparticles (CBSA-NPs), loaded with 6-coumarin was reported for brain delivery. Results revealed that CBSA-NPs uptake in rat brain capillary endothelial cells (BCECs) was enhanced as compared to control group BSA conjugated with pegylated nanoparticles (BSA-NP) BSA-NPs. Fluorescent microscopy of coronal brain sections displayed increased accumulation of CBSA-NPs than of BSA-NPs [53].

In the CMT mechanism, polymers NPs are designed to deliver drugs in order to take advantage of carrier molecules present in BBB. Polymer NPs are modified or decorated with membrane-penetrating components such as amino acids, peptides, and nutrients capable of transporting cargo across the BBB endothelial cells by utilising systemic transporters. For example, 2-deoxy-D-glucose modified poly (ethylene glycol)-co-poly (trimethylene carbonate) nanoparticles (DGlu-NPs) were studied for targeting the glioma BBB. The internalisation of DGlu-NP on RG-2 rat glioma cells was significantly higher than that of non-modified nanoparticles. This was attributed to the recognition of NPs by GLUT1 leading to enhanced cellular internalisation in glioma cells than in surrounding normal tissue and thus exhibiting promising in vivo anti-glioma activity [54]. 

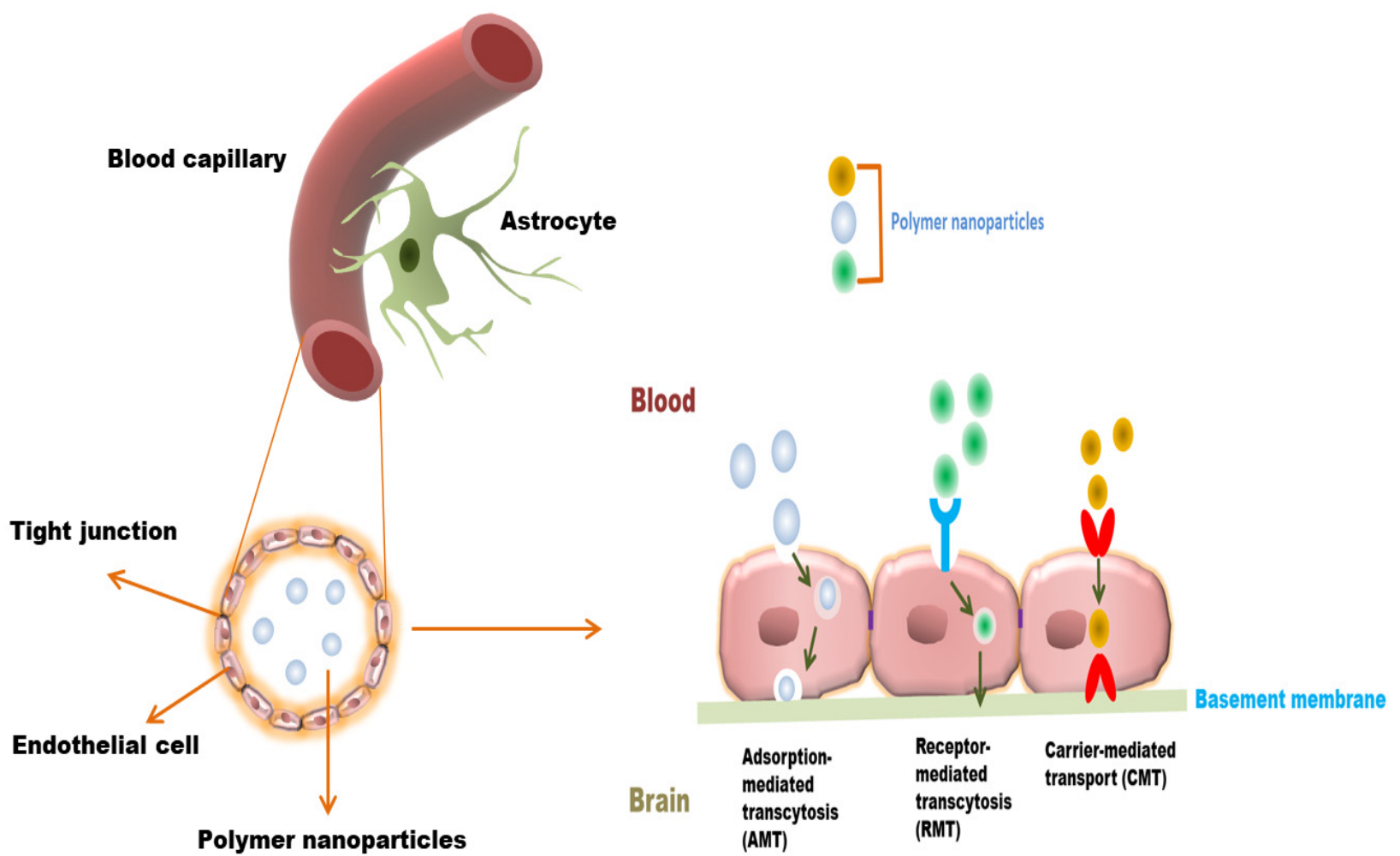

Figure 2. Various transport mechanisms of polymer NPs across blood-brain barrier (BBB).

Similarly, L-carnitine modified PLGA nanoparticles (LC-PLGA NPs) were designed to utilise the advantage of Na-coupled carnitine transporter 2 (OCTN2) expressions on brain capillary endothelial cells as glioma cells for BBB infiltration and targeting. Results showed increased accumulation of NPs in the BBB endothelial cell line (hCMEC/D3) and the glioma cell line (T98G). This revealed the Na dependent cellular uptake that involves OCTN2 in the NPs internalisation process. Moreover, a higher accumulation of LC-PLGA NPs was also observed in the in vivo mouse model study. Furthermore, loading of drugs Taxol and paclitaxel in the LC-PLGA NPs improved anti-glioma activity in both 2D-cell and 3D-spheroid models [46].

With the RMT mechanism, polymer NPs are decorated/designed with targeting ligands that bind to specific cell surface receptors highly expressed in BBB transport pathways. For example, the Transferrin receptor (TfR) is one of the primary targets for investigating RMT across the BBB because of its high expression on BBB/BBTB endothelium [55]. To evaluate in vivo BBB penetration and targeting efficacy, transferrin modified doxorubicin (DOX) and paclitaxel (PTX) loaded magnetic silica PLGA nanoparticles (MNP-MSN-PLGATf NPs) were developed. The nanoparticles were effectively accumulated in the tumour bearing mice suggesting that Tf facilitates NPs delivery across BBB [56].

Table 2. Summary of BBB permeability based on polymer-based nanoparticles.

\begin{tabular}{ccccc}
\hline $\begin{array}{c}\text { Polymer } \\
\text { Nanoparticles }\end{array}$ & Cargo & $\begin{array}{c}\text { Internalisation } \\
\text { Mechanism }\end{array}$ & $\begin{array}{c}\text { Cell Line/Animal } \\
\text { Model }\end{array}$ & Remarks \\
\hline $\begin{array}{c}\text { Trimethylated } \\
\text { chitosan } \\
\begin{array}{c}\text { TMC)-modified } \\
\text { PLGA NPs }\end{array}\end{array}$ & $\begin{array}{c}\text { Coenzyme Q10 } \\
\text { 6-coumarin }\end{array}$ & AMT & $\begin{array}{c}\text { SH-SY5Y cells, AD } \\
\text { transgenic mouse } \\
\text { brains }\end{array}$ & $\begin{array}{c}\text { Increase uptake of PLGA } \\
\text { nanoparticles, } \\
\text { neuroprotective effects of } \\
\text { Q10 observed } \\
\text { in TMC-PLGA NPs than } \\
\text { PLGA-NP. }\end{array}$ \\
\hline $\begin{array}{c}\text { Angiopep-2 modified } \\
\text { PLGA NPs }\end{array}$ & $\begin{array}{c}\text { Doxorubicin (DOX), } \\
\text { Epidermal growth } \\
\text { factor receptor } \\
\text { (EGFR) siRNA }\end{array}$ & RMT & $\begin{array}{c}\text { U87MG cells, brain } \\
\text { orthotopic U87MG } \\
\text { glioma xenograft } \\
\text { model }\end{array}$ & $\begin{array}{c}\text { Improved DOX and siRNA } \\
\text { cellular uptake, NPs able to } \\
\text { cross BBB. }\end{array}$ \\
\hline
\end{tabular}


Table 2. Cont.

\begin{tabular}{|c|c|c|c|c|c|}
\hline $\begin{array}{c}\text { Polymer } \\
\text { Nanoparticles }\end{array}$ & Cargo & $\begin{array}{l}\text { Internalisation } \\
\text { Mechanism }\end{array}$ & $\begin{array}{c}\text { Cell Line/Animal } \\
\text { Model }\end{array}$ & Remarks & References \\
\hline $\begin{array}{l}\text { Lactoferrin, folic acid } \\
\text { modified PLGA NPs }\end{array}$ & Etoposide & RMT & $\begin{array}{c}\text { HBMEC/HA } \\
\text { monolayer, U87MG } \\
\text { cells }\end{array}$ & $\begin{array}{l}\text { PLGA NPs cross BBB and } \\
\text { enhanced 2-fold uptake } \\
\text { with Lf-and FA. }\end{array}$ & [59] \\
\hline $\begin{array}{l}\text { RVG29 modified } \\
\text { PLGA NPs }\end{array}$ & Docetaxel & RMT & $\begin{array}{l}\text { C6 cells, bEnd } 3 \\
\text { monolayer BBB } \\
\text { model }\end{array}$ & $\begin{array}{l}\text { Better BBB penetration } \\
\text { in vitro. }\end{array}$ & [60] \\
\hline $\begin{array}{l}\text { OX26 Mab modified } \\
\text { PLGA NPs }\end{array}$ & $\begin{array}{l}\text { Temozolomide } \\
\text { (TMZ) }\end{array}$ & RMT & $\begin{array}{l}\text { U215 and U87, } \\
\text { in vitro HBLECs } \\
\text { monolayer model }\end{array}$ & $\begin{array}{l}\text { Improved TMZ } \\
\text { internalisation in } \\
\text { glioblastoma cells. }\end{array}$ & [61] \\
\hline $\begin{array}{l}\text { T7- modified, } \\
\text { magnetic PLGA } \\
\text { nanoparticulate } \\
\text { system (MNP/T7- } \\
\text { PLGA NPs) }\end{array}$ & $\begin{array}{l}\text { paclitaxel (PTX) and } \\
\text { curcumin (CUR) }\end{array}$ & RMT & $\begin{array}{l}\text { U87 cells and mouse } \\
\text { brain endothelial cell } \\
\text { line bEnd.3., mice } \\
\text { bearing orthotopic } \\
\text { glioma (U87-Luc) }\end{array}$ & $\begin{array}{l}>10 \text {-fold increase in cellular } \\
\text { uptake studies and a } \\
\quad>5 \text {-fold } \\
\text { enhancement in brain } \\
\text { delivery compared to the } \\
\text { non-functionalized NPs. }\end{array}$ & [62] \\
\hline $\begin{array}{c}\text { Angiopep conjugated } \\
\text { PEG-PCL } \\
\text { nanoparticles } \\
\text { (ANG-PEG-NP) }\end{array}$ & paclitaxel (PTX) & $\begin{array}{c}\text { RMT } \\
\text { (LRP-mediated } \\
\text { transcytosis) }\end{array}$ & $\begin{array}{l}\text { U87 MG, Male } \\
\text { BALB/c nude mice } \\
\text { and ICR mice }\end{array}$ & $\begin{array}{l}\text { The penetration, } \\
\text { distribution, and } \\
\text { accumulation into 3D } \\
\text { glioma spheroid and } \\
\text { in vivo glioma region of } \\
\text { ANG-PEG-NP was higher } \\
\text { than that of plain PEG-PCL } \\
\text { nanoparticles (PEG-NP). }\end{array}$ & [63] \\
\hline $\begin{array}{l}\text { dCatAlb encrusted } \\
\text { DOX-loaded PLGA } \\
\text { nanoparticle }\end{array}$ & Doxorubicin (DOX) & AMT & $\begin{array}{l}\text { monolayer bEnd. } 3 \\
\text { cells }\end{array}$ & Enhanced BBB permeation & [64] \\
\hline $\begin{array}{l}\text { cRGD } / \text { PEG-SS-PCL } \\
\text { micelles }\end{array}$ & Doxorubicin (DOX) & RMT & $\begin{array}{l}\text { U87MG glioma } \\
\text { xenografts }\end{array}$ & Efficient accumulation & [65] \\
\hline $\begin{array}{l}\text { DOX-loaded } \\
\text { cRGD-SS-NGs }\end{array}$ & Doxorubicin (DOX) & RMT & $\begin{array}{c}\text { U87-MG cells, } \\
\text { U87-MG } \\
\text { glioblastoma } \\
\text { xenograft in nude } \\
\text { mice }\end{array}$ & $\begin{array}{c}\text { Facilitated cellular uptake } \\
\text { and intracellular } \\
\text { DOX release }\end{array}$ & [66] \\
\hline $\begin{array}{l}\text { T7-PEG-PLGA } \\
\text { micelles }\end{array}$ & Carmustine (BCNU) & RMT & $\begin{array}{l}\text { U87-MG cells, } \\
\text { BALB/c nude mice }\end{array}$ & $\begin{array}{l}\text { Accumulation in tumour } \\
\text { more efficiently than } \\
\text { unconjugated one }\end{array}$ & [67] \\
\hline $\begin{array}{l}\text { PLGA based SSTR2 } \\
\text { pep-DIM-NPs }\end{array}$ & $\begin{array}{c}3,3^{\prime}- \\
\text { diindolylmethane }\end{array}$ & RMT & $\begin{array}{l}\text { C6 glioma cells, rat } \\
\text { Glioma model }\end{array}$ & $\begin{array}{l}\text { Accumulation of the NPs } \\
\text { into rat brain tumour sites } \\
\text { by crossing the BBB }\end{array}$ & [68] \\
\hline $\begin{array}{l}\text { L-carnitine modified } \\
\text { PLGA nanoparticles } \\
\text { (LC-PLGA NPs) }\end{array}$ & $\begin{array}{l}\text { Taxol and paclitaxel } \\
\text { (PTX) }\end{array}$ & CMT & $\begin{array}{l}\text { hCMEC/D3, } \\
\text { T98G cells }\end{array}$ & Efficient accumulation & [46] \\
\hline
\end{tabular}

Abbreviation: Adsorption-mediated transcytosis (AMT), carrier-mediated transport (CMT), and receptor-mediated transcytosis (RMT).

\section{Polymer Nanoparticles for Brain Cancer Therapy}

Polymer NPs are solid colloidal particles that can be utilised as carriers in which the therapeutic drugs or other active components are dissolved, entrapped, encapsulated, or adsorbed on the surface of the polymer matrix [69]. The structure of the polymer NPs can range from nanospheres to nanocapsules depending on the preparation procedure. Various polymers such as chitosan, gelatin, sodium alginate, albumin and polylactides (PLA), polyglycolides (PGA), poly(lactide co-glycolides) (PLGA), polyanhydrides, polyorthoesters, polycyanoacrylates, poly( $\varepsilon$-caprolactone), poly(glutamic acid), poly(malic acid), poly(Nvinyl pyrrolidone), poly(methyl methacrylate), poly(vinyl alcohol), poly(acrylic acid), poly(acrylamide), poly(ethylene glycol), poly(methacrylic acid) are mostly used in nanoparticle formation for both passive and ligand-functionalized actively targeted therapy [70]. Based on the nature of drugs to be loaded and their route of administration, different synthesis methods were implemented for the production of polymer NPs that include sol- 
vent evaporation, solvent diffusion, nanoprecipitation, emulsification, reverse salting out, nano-capsules nano-precipitation, layer-by-layer (LbL) method, etc. [71-73]. The molecular weight, crystallinity, and stability of polymers and the drug's physicochemical properties can be analysed to develop polymeric NPs for drug administration to the brain. Polymeric NPs have a unique ability to reach the tumour site through an active targeting route [74]. Researchers have developed docetaxel (DOC)-loaded PCL and its derivative poly (ethylene glycol)-block-poly( $\varepsilon$-caprolactone) methyl ether (mePEG-PCL) nanoparticles that were dispersed in a bioadhesive film and the formulation exhibited sustained release of drugs. Docetaxel-loaded nanoparticles induced more significant cytotoxicity than free docetaxel for glioma treatment [75]. The study reveals that glycopeptide-engineered poly(d,l-lactideco-glycolide (PLGA) NPs (g7-NPs) provides in vivo evidence of endocytosis of g7-NPs and transported into the endosomes, which help to cross BBB [76]. Gaudin and co-workers have demonstrated the use of convection-enhanced delivery (CED) of NPs for improved chemotherapeutic drugs to the tumour site. They successfully administered gemicitabine, a nucleoside analogue used for the wide range of solid tumours using squalene-based NPs. The study also revealed that PEGylation of the NPs with PEG dramatically improves the distribution of squalene-gemcitabine NPs in the tumours [77].

Most of the current nanomedicines approved by the FDA for clinical use for solid tumour treatment depend on the EPR effect. The enhanced permeability and retention effect or EPR effect is a feature that allows small sized nanoparticles and other active molecules or drugs to pass due to large pore size through leaky vasculature and accumulate in the tumor location.

The brain endothelial cells and glioblastoma cells generally overexpressed a number of receptors, including the low-density lipoprotein receptor, IL-13 receptor, transferrin receptor (TfR), and nicotine acetylcholine receptor that used as drug delivery targets in the brain [78]. Numerous in vivo studies revealed that polymer NPs could circulate for a longer time and accumulate in the tumour site. It is possible to enhance the retention and accumulation of these useful NPs by decorating NPs with tumour-homing ligands such as peptide, aptamer, polysaccharides, saccharides, antibodies, flic acids, etc. [79]. Recently, pluronic micelles (PEG-PPG-PEG) have evolved as perfect candidates for brain therapy, as they can easily cross the BBB and prove their ability to inhibit drug efflux [17]. For instance, Sun et al. developed TfR-T12 peptide-modified PEG-PLA polymer nanoparticle micelles loaded with paclitaxel (PTX) for glioma therapy. They found that the polymeric micelles (TfR-T12-PMs) could be absorbed by tumour cells, cross across BBB monolayers, and inhibit the proliferation of U87MG cells in vitro. A better antiglioma effect with a prolonged median survival of nude mice-bearing glioma was also observed in comparison with unmodified PMs [80]. This suggests that TfR-T12 peptide-modified micelles can cross the BBB system and target glioma cells. In Tables 3 and 4 are shown various synthetic and natural polymer-based NPs for GBMs therapy or diagnosis.

Recently, much research has been carried out on combined photo-based therapy along with other conventional therapy or imaging for glioblastoma treatment. For example, a novel photoacoustic and photothermal guided semiconducting polymer nanoparticles (SPNs) using poly (ethylene glycol)-block-poly (propylene glycol)-block-poly (ethylene glycol) (PEG-b-PPG-b-PEG) and SP were reported. The SPNs displayed efficient cellular internalisation for PAI and PTT toward U87 cells and accumulated in subcutaneous as well as brain tumours upon intravenous injection and induced efficient cell death upon NIR-II light irradiation [81].

The recent updates reveal that conjugated polymer nanoparticles (CPNs) are performing well as photosensitiser (PS) in photodynamic therapy (PDT). This efficiency is achieved by CPNs due to their uniform size, biocompatibility, and outstanding ROS production due to extraordinary photo-physical properties as well as fluorescence emission. It is found that porphyrin doped CPNs can eliminate GBMs through ROS-induced apoptotic damage [82]. 
Table 3. Synthetic polymer-based nanoparticles for brain cancer glioma therapy.

\begin{tabular}{|c|c|c|c|c|c|c|c|}
\hline Polymers & $\begin{array}{l}\text { Method of } \\
\text { Preparation }\end{array}$ & $\begin{array}{l}\text { Therapeutic } \\
\text { Drug/Other }\end{array}$ & $\begin{array}{c}\text { Targeting } \\
\text { Recep- } \\
\text { tor/Molecule }\end{array}$ & $\begin{array}{l}\text { Diagnostic } \\
\text { Component }\end{array}$ & $\begin{array}{c}\text { Cell } \\
\text { Line/Animal } \\
\text { Model }\end{array}$ & Remark & References \\
\hline $\begin{array}{c}\text { Synthetic } \\
\text { protein } \\
\text { nanoparticle } \\
\text { (SPNP) }\end{array}$ & $\begin{array}{l}\text { Electrohydrody } \\
\text { namic (EHD) } \\
\text { jetting }\end{array}$ & siRNA & STAT3i & $\begin{array}{c}\text { Alexa Fluor } \\
\text { 647- } \\
\text { labeled } \\
\text { albumin }\end{array}$ & $\begin{array}{c}\text { GL26 } \\
\text { syngeneic } \\
\text { mouse glioma } \\
\text { model }\end{array}$ & $\begin{array}{l}\text { Five-fold increase in } \\
\text { iRGD loaded SPNP in } \\
\text { glioma cell observed in } \\
\text { comparison to NPs } \\
\text { without iRGD. A total } \\
\text { of } 87.5 \% \text { of mice } \\
\text { developed anti-GBM } \\
\text { immunological } \\
\text { memory. }\end{array}$ & [83] \\
\hline $\begin{array}{l}\text { Porphyrin } \\
\text { doped } \\
\text { conjugated } \\
\text { polymer } \\
\text { nanoparticles } \\
\text { (CPNs) }\end{array}$ & $\begin{array}{l}\text { Controlled } \\
\text { nanoaggrega- } \\
\text { tion }\end{array}$ & - & m-RNA & DCF-DA & $\begin{array}{l}\text { U-87 MG, } \\
\text { T98G and } \\
\text { MO59K }\end{array}$ & $\begin{array}{l}\text { NPs enhance the } \\
\text { efficacy of PDT to } \\
\text { eliminate tumor via } \\
\text { ROS generation. } \\
\text { MO59K and U-87 MG } \\
\text { cells are died with CPN } \\
\text { having IC50 values } \\
8 \mathrm{mg} / \mathrm{L} \text { and } 9 \mathrm{mg} / \mathrm{L}, \\
\text { however, T98G cells are } \\
\text { found resistant to } \\
\text { CNP-PDT. }\end{array}$ & [84] \\
\hline PLGA & $\begin{array}{l}\text { Single- } \\
\text { emulsion, } \\
\text { solvent } \\
\text { evaporation } \\
\text { technique }\end{array}$ & Paclitaxel & - & - & $\begin{array}{c}\text { U87MG } \\
\text { with rats and } \\
\text { pigs' model }\end{array}$ & $\begin{array}{c}\text { Enhanced in vivo } \\
\text { efficacy }\end{array}$ & [85] \\
\hline PBAEs & $\begin{array}{l}\text { Step-wise } \\
\text { synthesis }\end{array}$ & DNA & & Cy3 dye & $\begin{array}{l}\text { BTICs from } \\
\text { patient }\end{array}$ & $\begin{array}{l}\text { More than } 60 \% \\
\text { transfection efficacy } \\
\text { is observed. }\end{array}$ & [86] \\
\hline $\begin{array}{l}\text { cRGD- } \\
\text { conjugated } \\
\text { PGNRs }\end{array}$ & $\begin{array}{l}\text { Ligand } \\
\text { exchange } \\
\text { method }\end{array}$ & - & $\begin{array}{c}\alpha_{\mathrm{V}} \beta_{\mathrm{V}-} \\
\text { integrin }\end{array}$ & - & U87MG & $\begin{array}{l}\text { cRGD-PGNRs is } \\
\text { proved having } \\
\text { excellent tumor } \\
\text { targeting ability, no } \\
\text { cytotoxicity, and } \\
\text { sufficient cellular } \\
\text { uptake. }\end{array}$ & [87] \\
\hline $\begin{array}{l}\text { Aptamer/gold } \\
\text { nanorod } \\
\text { conjugate }\end{array}$ & $\begin{array}{l}\text { Step-wise } \\
\text { synthesis }\end{array}$ & $\begin{array}{c}\mathrm{Sgc8} \\
\text { aptamer }\end{array}$ & Cell protein & Fluorescein & $\begin{array}{l}\text { Rat or mouse } \\
\text { model }\end{array}$ & $\begin{array}{c}\text { A total of } 99.09 \% \\
\text { binding affinity due to } \\
\text { the aptamers. } \\
\text { Complete destruction } \\
\text { of GMB on exposure to } \\
\text { LAER is observed. }\end{array}$ & [88] \\
\hline $\begin{array}{l}\text { Poly }(N- \\
\text { isopropylacryl- } \\
\text { amide)-based } \\
\text { nanogels and } \\
\text { magnetic NPs } \\
\text { composite }\end{array}$ & $\begin{array}{c}\text { Co- } \\
\text { polymerisation } \\
\text { and } \\
\text { co-evaporation }\end{array}$ & Ferrrofluid & - & $\begin{array}{l}\text { Sodium } \\
\text { fluorescein }\end{array}$ & Rat model & $\begin{array}{l}\text { The drug dose } \\
\text { delivered to tumor site } \\
\text { is directly proportional } \\
\text { to the duration of the } \\
\text { "on" pulse. }\end{array}$ & [89] \\
\hline $\begin{array}{c}\text { PEG-PBAE/ } \\
\text { ePBAE } \\
\text { nanoparticles } \\
\text { (NPs) }\end{array}$ & $\begin{array}{l}\text { Step wise } \\
\text { synthesis, } \\
\text { Michael } \\
\text { addition }\end{array}$ & $\begin{array}{c}\text { Plasmid } \\
\text { DNA, } \\
\text { pHSV-tk, } \\
\text { ganciclovir }\end{array}$ & - & $\begin{array}{c}\text { Hoechst } 33342 \\
\text { dye }\end{array}$ & $\begin{array}{l}\text { GBM1A and } \\
\text { BTIC375 } \\
\text { cells/Mice } \\
\text { model }\end{array}$ & $\begin{array}{c}\text { PEG-PBAE/ } \\
\text { ePBAE NP shows } 54 \\
\text { and } 82 \% \text { transfection } \\
\text { efficacies in GBM1A } \\
\text { and BTIC375 cells } \\
\text { while it is } 37 \text { and } 66 \% \\
\text { for optimised PBAE } \\
\text { NPs without PEG. } \\
\text { Death of cancer cell } \\
\text { with enhancement of } \\
\text { mice life time was } \\
\text { observed. }\end{array}$ & [90] \\
\hline
\end{tabular}


Table 3. Cont.

\begin{tabular}{|c|c|c|c|c|c|c|c|}
\hline Polymers & $\begin{array}{l}\text { Method of } \\
\text { Preparation }\end{array}$ & $\begin{array}{l}\text { Therapeutic } \\
\text { Drug/Other }\end{array}$ & $\begin{array}{c}\text { Targeting } \\
\text { Recep- } \\
\text { tor/Molecule }\end{array}$ & $\begin{array}{l}\text { Diagnostic } \\
\text { Component }\end{array}$ & $\begin{array}{c}\text { Cell } \\
\text { Line/Animal } \\
\text { Model }\end{array}$ & Remark & References \\
\hline TEB & $\begin{array}{c}\mathrm{Co}^{-} \\
\text {precipitation }\end{array}$ & - & $\begin{array}{l}\text { Transferrin } \\
\text { (TfR), } \\
\text { lactoferrin } \\
\text { (LfR) and } \\
\text { lipoprotein } \\
\text { (LRP) }\end{array}$ & - & $\begin{array}{l}\text { bEnd.3/Mouse } \\
\text { model }\end{array}$ & $\begin{array}{l}\text { Ligand-coated TEB } \\
\text { nanoparticles are } \\
\text { transported across BBB } \\
\text { with high efficacy. }\end{array}$ & [91] \\
\hline PEG-PLA & $\begin{array}{l}\text { Emulsion/ } \\
\text { solvent } \\
\text { evaporation } \\
\text { technique }\end{array}$ & & $\begin{array}{l}\text { Neuropilin } \\
\text { (NRP), } \\
\text { tLyp-1 } \\
\text { peptide }\end{array}$ & & $\begin{array}{l}\text { Human } \\
\text { umbilical vein } \\
\text { endothelial } \\
\text { cells and Rat } \\
\text { C6 glioma cells }\end{array}$ & $\begin{array}{l}\text { tLyp-1 peptide } \\
\text { functionalised NPs } \\
\text { show better } \\
\text { performance in } \\
\text { paclitaxel glioma } \\
\text { therapy. Observed } \\
\text { inhibition of avascular } \\
\text { C6 glioma spheroids. } \\
\text { Interestingly } \\
\text { tLyp-1-NP-PTX } \\
\text { formulations shows } \\
\text { higher antiproliferation } \\
\text { ability with IC50 0.087 } \\
\text { mg/mL in comparison } \\
\text { to NP-PTX } \\
\text { and Taxol. }\end{array}$ & [92] \\
\hline $\begin{array}{l}\text { Transferrin } \\
\text { modified } \\
\text { PEG-PLA }\end{array}$ & $\begin{array}{l}\text { Double } \\
\text { emulsion and } \\
\text { solvent } \\
\text { evaporation } \\
\text { method. }\end{array}$ & $\begin{array}{l}\text { Resveratrol } \\
\quad \text { (RSV) }\end{array}$ & - & - & $\begin{array}{l}\text { C6 and U87 } \\
\text { glioma cells }\end{array}$ & $\begin{array}{c}\text { RSV-conjugates } \\
\text { decreased brain tumor } \\
\text { volume and } \\
\text { accumulated well in } \\
\text { comparison to free RSV. }\end{array}$ & [93] \\
\hline $\begin{array}{l}\text { Polysorbate- } \\
\text { coated } \\
\text { NPs }\end{array}$ & $\begin{array}{c}\text { Surfactant } \\
\text { mediated } \\
\text { ultrasonication }\end{array}$ & $\begin{array}{l}\text { Doxorubicin } \\
\text { (DOX) }\end{array}$ & - & $\begin{array}{l}\text { Evans Blue } \\
\text { solution }\end{array}$ & $\begin{array}{c}\text { Glioblastoma } \\
\text { 101/8-bearing } \\
\text { rats }\end{array}$ & $\begin{array}{l}\text { Enhanced permeability } \\
\text { and retention effect }\end{array}$ & [94] \\
\hline PCL & $\begin{array}{l}\text { Solvent } \\
\text { evaporation } \\
\text { technique }\end{array}$ & $\begin{array}{l}\text { Irinotecan } \\
\text { hydrochlo- } \\
\text { ride } \\
\text { trihydrate } \\
\text { (IRH) }\end{array}$ & - & - & HGG cells & $\begin{array}{l}\text { IRH-loaded PCL NPs } \\
\text { has excellent anti-brain } \\
\text { tumor activity. PCL } \\
\text { shows better drug } \\
\text { encapsulation than } \\
\text { PLGA. }\end{array}$ & [95] \\
\hline $\begin{array}{l}\text { cRGD-directed } \\
\text { AuNR/PEG- } \\
\text { PCL hybrid } \\
\text { NPs }\end{array}$ & Nanoprecipitation & $\begin{array}{l}\text { Doxorubicin } \\
\text { (DOX) }\end{array}$ & & Cy7 & $\begin{array}{l}\text { Human } \\
\text { U87MG glioma }\end{array}$ & $\begin{array}{c}\text { Controlled release of } \\
\text { doxorubicin } \\
\text { into human } \\
\text { glioblastoma using } \\
\text { mice model is achieved } \\
\text { that leads to inhibition } \\
\text { of } 100 \% \text { tumour } \\
\text { growth. }\end{array}$ & [96] \\
\hline $\begin{array}{l}\text { PCL-Diol-b- } \\
\text { PU/gold } \\
\text { nanofiber } \\
\text { composite }\end{array}$ & & $\begin{array}{l}\text { Temozolomide } \\
\text { (TMZ) }\end{array}$ & & & $\begin{array}{c}\text { U-87 MG } \\
\text { human } \\
\text { glioblastoma } \\
\text { cells }\end{array}$ & $\begin{array}{l}\text { Slower release of TMZ } \\
\text { showing its high } \\
\text { potential as } \\
\text { implantable device for } \\
\text { drug release. Enhanced } \\
\text { activity against the } \\
\text { U-87 cell. }\end{array}$ & [97] \\
\hline $\begin{array}{l}\text { PEG-PCL NPs } \\
\text { conjugated } \\
\text { with ALMWP }\end{array}$ & $\begin{array}{l}\text { Emulsion/solvent } \\
\text { evaporation } \\
\text { method }\end{array}$ & $\begin{array}{l}\text { Paclitaxel } \\
\text { (PTX), } \\
\text { Taxol }\end{array}$ & - & coumarin-6 & C6 cells & $\begin{array}{l}\text { Animals treated for C6 } \\
\text { gliomas with } \\
\text { ALMWP-NP-PTX } \\
\text { survive longer than } \\
\text { those treated with } \\
\text { Taxol-NP-PTX. }\end{array}$ & [98] \\
\hline
\end{tabular}

Abbreviation: PLG: poly(lactide-coglycolide), DCF-DA: $2^{\prime}, 7^{\prime}$-dichlorofluorescin-diacetate PBAEs: poly ( $\beta$-amino ester) s, cRGD: cyclic RGD peptides, PGNRs: PEGylated gold nanorods, PEG: polyethylene glycol, PSMA: prostate-specific membrane antigen, NR: nanorods, PCL-diol: poly ( $\varepsilon$-caprolactone diol), PU: polyurethane, ALMWP: activatable low molecular weight protamine. 
Table 4. Natural polymer-based nanoparticles for brain cancer glioma therapy.

\begin{tabular}{|c|c|c|c|c|c|c|c|}
\hline $\begin{array}{c}\text { Natural } \\
\text { Polymer- } \\
\text { Based } \\
\text { Nanoparticles }\end{array}$ & $\begin{array}{l}\text { Method of } \\
\text { Preparation }\end{array}$ & $\begin{array}{l}\text { Therapeutic } \\
\text { Drug/Other }\end{array}$ & $\begin{array}{l}\text { Targeting } \\
\text { Recep- } \\
\text { tor/Molecule }\end{array}$ & $\begin{array}{l}\text { Diagnostic } \\
\text { Component }\end{array}$ & $\begin{array}{c}\text { Cell } \\
\text { Line/Animal } \\
\text { Model }\end{array}$ & Remark & References \\
\hline $\begin{array}{l}\text { Den-angio } \\
\text { nanoprobe }\end{array}$ & $\begin{array}{l}\text { Step-wise } \\
\text { synthesis }\end{array}$ & - & $\begin{array}{l}\text { LRP receptor- } \\
\text { mediated } \\
\text { endocytosis }\end{array}$ & & U87MG & $\begin{array}{l}\text { Den-Angio shows } \\
\text { localisation in the brain } \\
\text { tumours and makes } \\
\text { image-guided tumour } \\
\text { resection possible. }\end{array}$ & [99] \\
\hline CDP-NP & $\begin{array}{l}\text { Single-step } \\
\text { synthesis at } \\
\text { room } \\
\text { temperature, } \\
\text { self-assembly } \\
\text { method }\end{array}$ & - & Proteins & e-GFP, luciferin & $\begin{array}{l}\text { BV2, N9 } \\
\text { microglia (MG) } \\
\text { cells and } \\
\text { GL261 glioma } \\
\text { cells/mice } \\
\text { model }\end{array}$ & $\begin{array}{l}\text { CDP-NPs were } \\
\text { efficiently taken up by } \\
\text { BV2 and N9 microglia } \\
\text { (MG) cells compared to } \\
\text { GL261 glioma cells. }\end{array}$ & [100] \\
\hline $\begin{array}{c}\text { Silver NPs } \\
\text { impregnated } \\
\text { alginate- } \\
\text { chitosan- } \\
\text { blended } \\
\text { nanocarrier }\end{array}$ & $\begin{array}{l}\text { Polyelectrolyte } \\
\text { complex } \\
\text { formation } \\
\text { reaction }\end{array}$ & & DNA & $\begin{array}{l}\text { Acridine Or- } \\
\text { ange/Ethidium } \\
\text { Bromide dual } \\
\text { stain }\end{array}$ & U87MG & $\begin{array}{c}\text { Extensive DNA } \\
\text { damage was observed } \\
\text { on cell cycle analysis. }\end{array}$ & [101] \\
\hline $\begin{array}{l}\text { Hyaluronan } \\
\text { (HA)-grafted } \\
\text { lipid-based } \\
\text { NPs (LNPs) }\end{array}$ & $\begin{array}{l}\text { Amine } \\
\text { coupling } \\
\text { strategy }\end{array}$ & $\begin{array}{c}\text { rRNA } \\
\text { interference } \\
\text { (RNAi), } \\
\text { doxorubicin } \\
\text { and BCNU }\end{array}$ & $\begin{array}{l}\mathrm{CD} 44 \\
\text { receptor }\end{array}$ & DAPI (blue) & $\begin{array}{l}\text { T98G, U87MG, } \\
\text { and U251 }\end{array}$ & $\begin{array}{l}\text { Prolonged survival of } \\
\text { treated mice in the } \\
\text { orthotopic model was } \\
\text { observed. }\end{array}$ & [102] \\
\hline $\begin{array}{l}\text { Cardamom } \\
\text { extract-loaded } \\
\text { gelatine NPs } \\
\text { (CE-loaded } \\
\text { GNPs) }\end{array}$ & $\begin{array}{l}\text { Two-step } \\
\text { de-solvation } \\
\text { method }\end{array}$ & $\begin{array}{l}\text { Cardamom } \\
\text { extract }\end{array}$ & - & - & U87MG & $\begin{array}{l}\text { Extract to polymer } \\
\text { ratio as 1:20 was found } \\
\text { to be the best with } \\
\text { entrapment. efficiency } \\
\text { close to } 70 \%\end{array}$ & [103] \\
\hline $\begin{array}{l}\text { NK@AIEdots } \\
\text { (natural-killer- } \\
\text { cell-mimic } \\
\text { nanorobots } \\
\text { with } \\
\text { aggregation- } \\
\text { induced } \\
\text { emission) }\end{array}$ & $\begin{array}{l}\text { Step-wise } \\
\text { synthesis, } \\
\text { assembly } \\
\text { process }\end{array}$ & - & - & - & $\begin{array}{l}\text { U-87 MG, } \\
\text { bEnd.3 }\end{array}$ & $\begin{array}{l}\text { The tumour growth } \\
\text { was also successfully } \\
\text { inhibited by } \\
\text { NK@AIEdots on } \\
\text { exposure to NIR light. }\end{array}$ & [104] \\
\hline $\begin{array}{c}\text { Heparin-based } \\
\text { polymer)- } \\
\text { SWL-(cRGD) } \\
\text { NPs } \\
(\mathrm{S}=\text { serine, } \mathrm{W} \\
=\text { tryptophan, } \\
\mathrm{L}=\text { leucine })\end{array}$ & $\begin{array}{l}\text { Coupling } \\
\text { reaction }\end{array}$ & & $\begin{array}{l}\alpha_{\mathrm{V}} \beta_{\mathrm{V}} \text { and } \\
\text { EphA2 in } \\
\text { glioma }\end{array}$ & $\begin{array}{l}\text { f Oregon- } \\
\text { green } 488\end{array}$ & U87 and U251 & $\begin{array}{c}\text { NPs easily } \\
\text { pass-through BBB to } \\
\text { the tumour site. In } \\
\text { addition, inhibition of } \\
\text { glioma cell } \\
\text { proliferation is noticed. }\end{array}$ & [105] \\
\hline $\begin{array}{l}\text { poly-L- } \\
\text { arginine- } \\
\text { chitosan- } \\
\text { triphosphate } \\
\text { matrix (ACSD) }\end{array}$ & $\begin{array}{l}\text { Green co- } \\
\text { precipitation } \\
\text { method }\end{array}$ & $\begin{array}{l}\text { Doxorubicin, } \\
\text { SPIONs }\end{array}$ & - & $\begin{array}{l}\text { Prussian blue } \\
\text { staining and } \\
\text { inductively } \\
\text { coupled } \\
\text { plasma }\end{array}$ & $\begin{array}{l}\text { Rat glioma C6 } \\
\text { cells }\end{array}$ & $\begin{array}{l}\text { ACSD NPs are proved } \\
\text { as promising } \\
\text { theranostic formulation } \\
\text { MRI analysis shows } \\
\text { uptake of NPs in } \\
\text { C6 glioma cells. There } \\
\text { observed } 38.6 \% \text { drug } \\
\text { release in neutral pH } \\
\text { while } 58 \% \text { in acidic pH. } \\
\text { A } 44-\text {-fold increase in } \\
\text { IC }_{50} \text { value of } \\
\text { doxorubicin was found } \\
\text { when the drug was } \\
\text { loaded in NPs. }\end{array}$ & [106] \\
\hline
\end{tabular}


Table 4. Cont.

\begin{tabular}{|c|c|c|c|c|c|c|c|}
\hline $\begin{array}{c}\text { Natural } \\
\text { Polymer- } \\
\text { Based } \\
\text { Nanoparticles }\end{array}$ & $\begin{array}{l}\text { Method of } \\
\text { Preparation }\end{array}$ & $\begin{array}{l}\text { Therapeutic } \\
\text { Drug/Other }\end{array}$ & $\begin{array}{c}\text { Targeting } \\
\text { Recep- } \\
\text { tor/Molecule }\end{array}$ & $\begin{array}{l}\text { Diagnostic } \\
\text { Component }\end{array}$ & $\begin{array}{c}\text { Cell } \\
\text { Line/Animal } \\
\text { Model }\end{array}$ & Remark & References \\
\hline $\begin{array}{c}\text { Albumin } \\
\text { nanoparticles } \\
\text { (NPs) }\end{array}$ & $\begin{array}{l}\text { Two-step } \\
\text { synthesis, } \\
\text { grafting }\end{array}$ & $\begin{array}{l}\text { Paclitaxel } \\
\text { (PTX) }\end{array}$ & $\begin{array}{l}\text { Substance P } \\
(\mathrm{SP}) \text { peptide }\end{array}$ & Cou-6 dye & $\begin{array}{l}\text { Glioma U87 } \\
\text { cells }\end{array}$ & $\begin{array}{l}\text { Albumin nanoparticles } \\
\text { are found satisfactory } \\
\text { for drug delivery } \\
\text { vehicles for the } \\
\text { treatment of GBM. The } \\
\text { targeting effect of SP, } \\
\text { and efficient cellular } \\
\text { uptake of SP-HSA-PTX } \\
\text { NPs into brain capillary } \\
\text { endothelial cells } \\
\text { (BCECs) and U87 cells } \\
\text { is improved. }\end{array}$ & [107] \\
\hline $\begin{array}{l}\text { Human serum } \\
\text { albumin (HSA) } \\
\text { NPs }\end{array}$ & $\begin{array}{l}\text { High-pressure } \\
\text { homogeniser } \\
\text { technique }\end{array}$ & Doxorubicin & - & LysoTracker & $\begin{array}{l}\text { bEnd. } 3 \text { cells as } \\
\text { well as U87MG }\end{array}$ & $\begin{array}{l}\text { Anti-glioma efficacy is } \\
\text { improved due to the } \\
\text { dual-enhanced system } \\
\text { of dual cationic } \\
\text { absorptive transcytosis } \\
\text { and glucose-transport } \\
\text { by using c- and m-HSA } \\
\text { together. }\end{array}$ & [108] \\
\hline Albumin NPs & $\begin{array}{c}\text { Green } \\
\text { synthesis }\end{array}$ & $\begin{array}{l}\text { Paclitaxel } \\
\text { and } \\
\text { fenretinide }\end{array}$ & - & CY5 dye & $\begin{array}{l}\text { Human glioma } \\
\text { U87, U251 cells, } \\
\text { mouse glioma } \\
\text { C6, GL261 } \\
\text { cells, }\end{array}$ & $\begin{array}{l}\text { The albumin-binding } \\
\text { proteins are found to be } \\
\text { overexpressed in the } \\
\text { tumour/glioma cells, } \\
\text { where epithelium cells } \\
\text { are responsible for } \\
\text { delivering NPs to brain } \\
\text { tumours. }\end{array}$ & [109] \\
\hline $\begin{array}{l}\text { Menthol- } \\
\text { modified } \\
\text { casein NPs(M- } \\
\text { CA-NP) }\end{array}$ & $\begin{array}{l}\text { Self-assembled } \\
\text { micelle } \\
\text { formation }\end{array}$ & \multicolumn{2}{|c|}{$\begin{array}{l}10- \\
\text { Hydroxycamptothecin,- } \\
\text { methanol }\end{array}$} & Cou-6 & C6 cells & $\begin{array}{l}\text { Resulted in enhanced } \\
\text { drug accumulation in } \\
\text { the tumour site. }\end{array}$ & [110] \\
\hline $\begin{array}{l}\text { Transferrin- } \\
\text { functionalised } \\
\text { NPs (Tf-NP) }\end{array}$ & Functionalisation & $\begin{array}{l}\text { Temozolomide } \\
\text { and the bro- } \\
\text { modomain }\end{array}$ & & Cy5.5 & $\begin{array}{l}\text { U87MG and } \\
\text { GL261 cells }\end{array}$ & $\begin{array}{l}\text { Therapy showed 1.5- to } \\
\text { 2-fold decrease in } \\
\text { tumor burden and } \\
\text { corresponding increase } \\
\text { in survival in tumor } \\
\text { bearing mice }\end{array}$ & [111] \\
\hline
\end{tabular}

Abbreviation: Den: dendrimer, Angio: angiopep-2, PDT: photodynamic therapy, CDP-NP: cyclodextrin-based nanoparticle, TEB: triphenylamine-4-vinyl- (P-methoxy-benzene), DAPI: 4' ,6-diamidino-2-phenylindole, SPIONs: superparamagnetic iron oxide nanoparticles.

\section{Polymer Nanoparticles in the Diagnosis of Brain Cancer}

Before surgery, a high-resolution image using imaging modalities is required for glioma detection. Owing to the invasiveness of glioma cells, determining the exact tumour boundary by eye is challenging. Proper imaging of a tumour is essential for assessing the extent of tumour distribution before surgery and the response to a treatment regimen after surgery [5]. Several available techniques for visualisation and diagnosis of brain cancer glioma include optical and ultrasound (US) imaging, photoacoustic (PA) imaging, computed tomography (CT), positron emission tomography (PET), single-photon emission computed tomography (SPECT) and fluorescence (FL) imaging techniques (Figure 3) [112] Currently, magnetic resonance imaging (MRI), a non-invasive technique that can detect the size, shape, and tumour location, is initially employed diagnostic method for patients with suspected GBM [113]. MRI can determine the boundaries of the tumour tissues and/or intraoperative to elucidate tumour outline during surgical resection by applying gadolinium (Gd). Due to a shorter half-life, Gd must be administered often to maintain blood levels for efficient scanning. The use of intraoperative ultrasonography to obtain integrated brain tissue imaging is another non-optical method. However, this approach 
does not provide enough information for detecting smaller or superficial brain tumours. Other invasive techniques for analysing brain tumour tissues include Raman spectroscopy, optical coherence tomography, fluorescence spectroscopy, and thermal imaging [114]. Computed tomography (CT) can also be used to determine the presence of the tumour. Still, its use is relatively lesser in clinics for diagnosing GBM due to poor resolution compared to MRI [115]. Likewise, positron emission tomography (PET) imaging with 11C-methionine could be an effective diagnostic tool for GBM patients' prognosis [116,117]. To understand cancer tumours, precise preoperative imaging and painless sensitive postimaging techniques to provide real-time data are demanded. Current imaging modalities, however, lack accuracy, sensitivity, and specificity. Nanotechnology has sparked interest in bioimaging and biosensing in recent years.

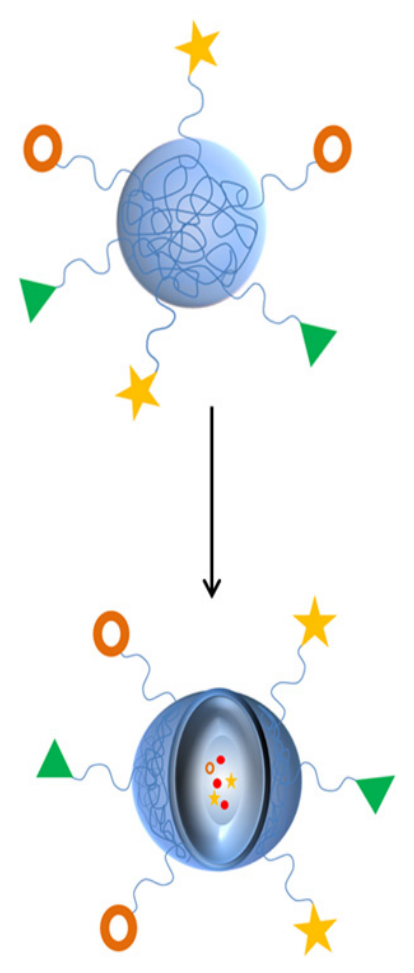

Polymer nanoparticles

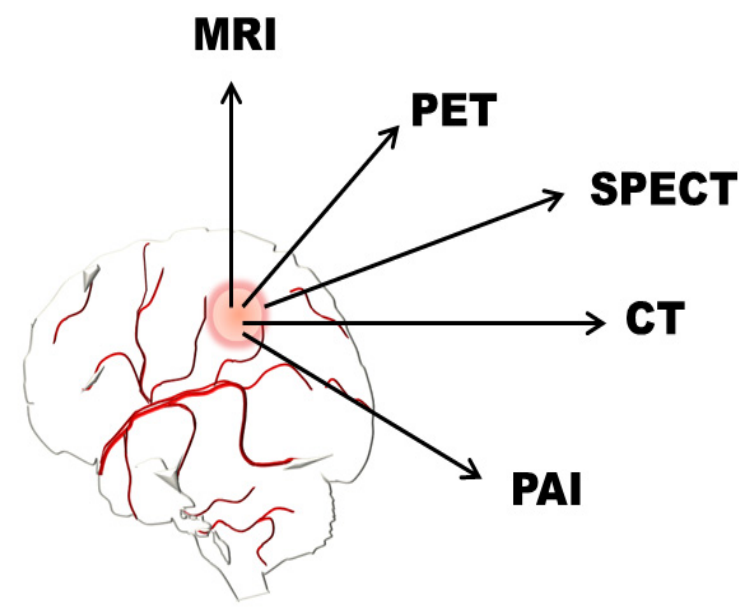

Brain with tumor

Figure 3. Polymer NPs in imaging for improved diagnosis of brain cancer.

'Nanodiagnostics' combined with nanotechnology could provide a drug delivery system with traditional diagnostic and imaging procedures [118,119]. Nanotechnology has made it easier to acquire data with great precision and accuracy while avoiding invasive procedures. NPs with tunable optical, magnetic, and electrical properties are able to provide diagnostic tools for detection and imaging brain cancer/tumours [120]. Biocompatible NPs owing ideal physical characteristics, such as surface chemistry, morphology, solubility, stability, etc., facilitate drug delivery and imaging as it acts as image contrast agents [121]. Polymer NPs could be a good reservoir system for drugs and a platform for additional modification for efficient tumour targeting or imaging [122]. Polymer NPs possess various advantages in drug delivery to the brain that can entrap or carry drugs that prevent them from metabolism and excretion. Moreover, NPs can easily transport drugs across the BBB without changing the barrier properties [31,123,124]. In this section, polymer NPs utilised in the diagnosis and detection of brain cancer glioma until now are primarily focused. The imaging and diagnosis techniques currently being investigated with reference to polymer NPs are listed in Table 5. 
Polymer-based superparamagnetic NPs have mainly been employed as drug delivery systems and contrast agents in MRI imaging. These NPs are highly stable and biocompatible, can prolong systemic circulation time, have drug loading ability and control of drug release, and combine with their magnetic performance for MRI [125]. Ganipineni et al. synthesised paclitaxel (PTX) and superparamagnetic iron oxide (SPIO)-loaded PEGylated PLGA-based NPs (PTX/SPIONPs) and analysed for therapeutic efficacy in an orthotopic U87MG model. The cellular internalisation of these NPs was found to be concentration dependent. The MRI scanning displayed the blood-brain barrier disruption in the glioma affected location. Moreover, enhanced accumulation was also observed in ex vivo biodistribution analysis of GBM-bearing mice with magnetic targeting [126]. Researchers have evaluated SPIO-loaded brain penetrating PLGA NPs by CED administration on rat models and visualised using positron emission tomography (PET) and MRI [127]. SPIO-loaded NPs showed excellent transverse (T2) relaxivity. After CED of NPs, the biodistribution in the brain was analysed using MRI, which revealed a period of one month longer signal attenuation of SPIO-loaded brain-penetrating PLGA NPs. The co-administration of SPIO-loaded PLGA NPs allows intraoperative monitoring of biodistribution in the brain in order to ensure the delivery to tumour location and therapeutic effect over time [127]. Researchers have developed Polysorbate 80 coated temozolomide-loaded PLGA-based superparamagnetic nanoparticles (P80- TMZ/SPIO-NPs), evaluated for anti-glioma activity and analysed as a diagnostic agent for MRI [128]. The superparamagnetic P80-TMZ/SPIONPs showed a significant antiproliferative effect and remarkable cellular internalisation on C6 glioma cells. Moreover, the in vitro MRI scanning revealed that P80-TMZ/SPIO-NPs could also serve as a good contrast agent [128].

Table 5. Polymer nanoparticles in imaging and diagnosis of brain cancer therapy.

\begin{tabular}{|c|c|c|c|c|c|}
\hline Nanoparticles & Detection Method & Cell Line & Animal Model & Therapy/Drug & References \\
\hline $\begin{array}{l}\text { SPIONs and DOX loaded poly-l- } \\
\text { arginine-chitosan-triphosphate } \\
\text { matrix (ACSD) NPs }\end{array}$ & MRI & C6 glioma cells & - & DOX & [106] \\
\hline $\begin{array}{l}\text { P80- TMZ/SPIO-NPs (PLGA } \\
\text { coating) }\end{array}$ & MRI & C6 glioma cells & - & TMZ & [128] \\
\hline $\begin{array}{l}\text { Micelles SPION and Au NPs } \\
\quad \text { (PEG-PCL coating) }\end{array}$ & MRI, CT & - & $\begin{array}{l}\text { U251 xenograft and } \\
\text { orthotopic brain } \\
\text { tumour models. }\end{array}$ & Radiotherapy & [129] \\
\hline $\begin{array}{l}\text { Chitosan-dextran } \\
\text { superparamagnetic NPs } \\
\text { (CS-DX-SPIONs) }\end{array}$ & MRI & C6 glioma, U87 & $\begin{array}{l}\text { orthotopic C6 gliomas } \\
\text { in rats }\end{array}$ & - & [130] \\
\hline DOX-Ps@80-SPIONs & MRI & glioblastoma C6 cells & Glioma-bearing rats & DOX & [131] \\
\hline $\begin{array}{c}\text { Paclitaxel (PTX) and } \\
\text { superparamagnetic iron oxide } \\
\text { (SPIO)-loaded PEGylated poly } \\
\text { (lactic-co-glycolic acid) } \\
\text { (PLGA)-based } \\
\text { NPs(PTX/SPIONPs) }\end{array}$ & MRI & - & $\begin{array}{l}\text { orthotopic U87MG } \\
\text { model }\end{array}$ & PTX & [126] \\
\hline $\begin{array}{l}\text { SPIO-loaded brain penetrating } \\
\text { PLGA NPs }\end{array}$ & PET, MRI & - & rat model & - & [127] \\
\hline $\begin{array}{c}{\left[{ }^{18} \mathrm{~F}\right] \text { NPB4-labeled and C6-loaded }} \\
\text { PLGA NPs }\end{array}$ & PET & - & $\begin{array}{l}\text { rats bearing } \\
\text { BCSC-derived } \\
\text { xenografts }\end{array}$ & - & [85] \\
\hline $\begin{array}{l}\text { TMZ and iron oxide-containing } \\
\text { polymer NPs(PMNPs) }\end{array}$ & MRI & U87 glioma cells & rodent model & TMZ & [132] \\
\hline
\end{tabular}

Abbreviation: $N-\left(4-\left[{ }^{18} \mathrm{~F}\right]\right.$ fluorobenzyl) propanamido-PEG 4 -Biotin, brain cancer stem cells (BCSCs).

\section{Limitations and Challenges}

From the past times, tremendous developments have been evidenced in brain cancer therapy. Yet, there have not been emerged significant changes in mortality rate and 
improving patients' quality of life. Although nanoparticle-based drug delivery systems have brought a new horizon, many challenges remain and need to be solved in the future. The development of effective polymeric NPs for drug delivery and targeting is a challenging task for clinical translations. The advantage and limitations are summarised in Figure 4. The toxicity of these systems is one of the main challenges. The slow degradation rate of polymer NPs induce a longer circulation time in the body and could cause unknown complications.

Further, extensive investigations are required for optimization of the NPs. One of the major obstacles in clinical translation is the interaction of NPs and biological systems. Upon entering the complicated biological system, the designed polymeric NPs will instantly interact with neighboring biomolecules, leading to the formation of protein corona that alters their properties. This affects NPs size, stability, surface properties and determines the pharmacokinetics, biodistribution, cellular internalisation, intracellular trafficking, immune system, and toxicity [133-136]. In addition, more in vitro and in vivo studies are required to better understand the mechanisms in targeted nanoparticle-based therapy. Several essential factors related to the in vivo behaviour of NPs and their effect on other healthy brain cells are hence required to be extensively examined. Currently, there is still insufficient pre-clinical data of polymer-based NPs on brain delivery, data to correlate in vitro-in vivo observation, which makes it difficult to conclude about their therapeutic efficacy.

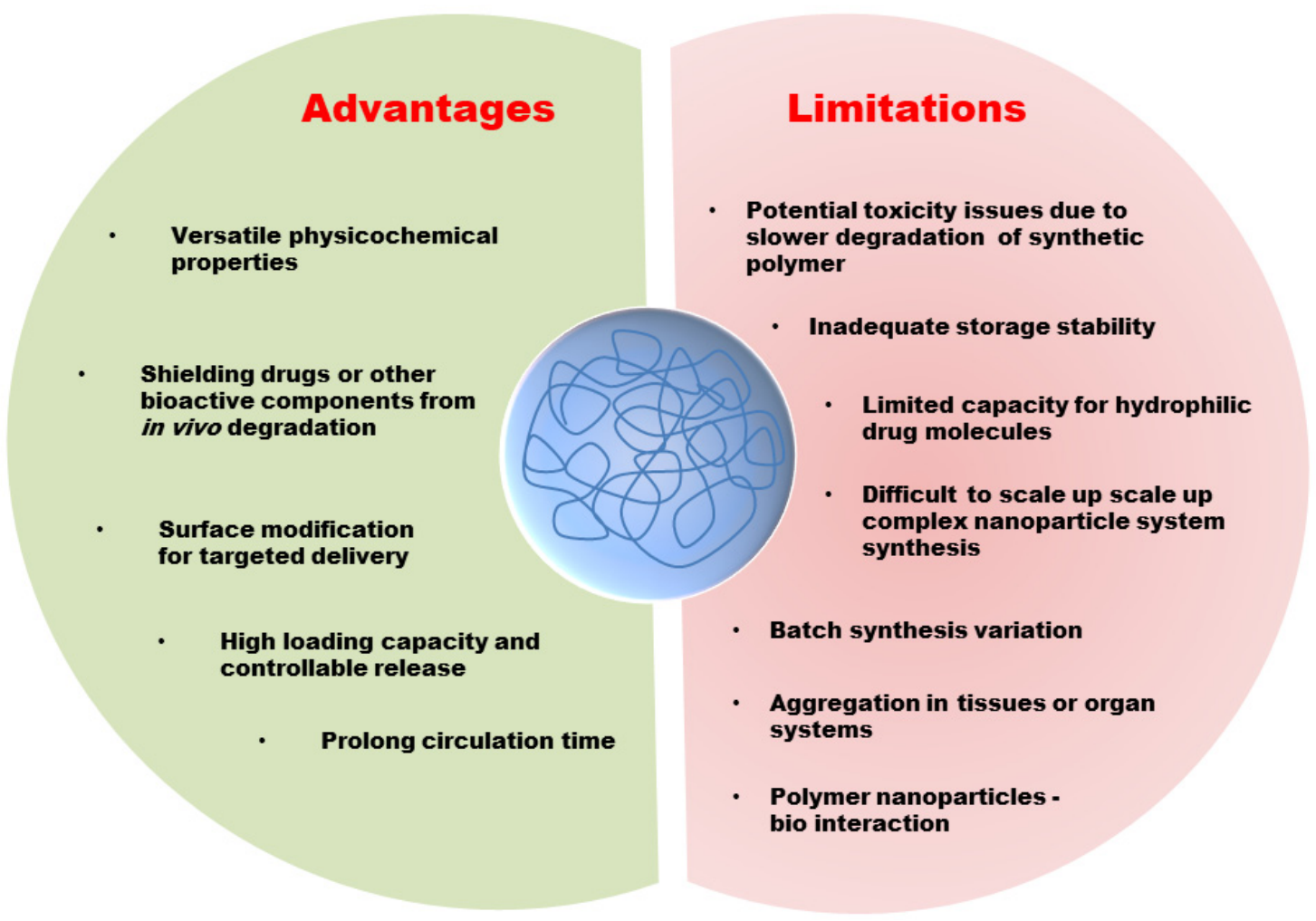

Figure 4. The advantages and limitations of polymer NPs in drug delivery and therapy.

\section{Future Perspective and Conclusions}

Glial originated brain cancers are the most aggressive gliomas that depict a threat to humans. The conventional therapies are still inefficient to overcome due to tumor heterogeneity and, specifically, the blood-brain barrier (BBB) of malignant gliomas. The polymeric nanoparticles-based brain cancer therapy approaches are currently gaining interest due to the drug safety, controllable drug release, and efficient targeting in tumors. Most importantly, reports revealed that polymer NPs could even transport across BBB. In this review article, we summarize the newest breakthroughs in the use of polymer nanocarriers for drug delivery, therapy and diagnosis of brain cancer are explored, emphasizing how 
they are a critical aspect of modern anticancer drug delivery strategies. Various polymer NPs have been generated to reduce anticancer drug losses, premature degradation, enhance drug availability, and reduce drug toxicity by improving drug accumulation in specific organs and tissues. Although the potential impact of polymer NPs in cancer therapy is exceedingly promising, numerous obstacles that currently limit their widespread clinical usage must be solved. For polymer NPs to be used in clinical trials, long-term safety investigations must be conducted in various animal models to eliminate the possibility of non-endogenous components accumulating in the body causing any harm. As a result, huge costs must be provided when conducting in vivo pharmacokinetic studies to evaluate the applicability in the human body. Another factor to consider is the challenges that may arise when transitioning from laboratory to large-scale production. The scaling up of the preparatory process is a major obstacle that must be surmounted. A significant number of polymer NPs are currently in the pre-clinical stage of development, but only one system has entered a clinical study. This is primarily because several challenges impede further development, such as a lack of potency in animal models and toxicity concerns. To overcome the aforementioned concerns, researchers need to focus more on new therapeutic innovations such as revising fabrication processes to modify and improve polymeric NPs in order to accommodate the demand for various anticancer drugs for effective clinical feasibility. New therapeutic innovations also include novel therapeutic strategies for combination therapy and stimuli-activated drug delivery. For example, delivering two or more anticancer drugs simultaneously might enhance the treatment of various cancer developments by targeting different tumour related signalling pathways, resulting in a synergistic therapeutic impact. In addition, the researcher needs to improve the targeting of cancer stem cells (CSCs) for effective cancer therapeutic effect as CSCs is a critical factor for tumour recurrence. In conclusion, pre-clinical experimentation and clinical trials are mandatory for an efficient polymer nanoparticle-based anticancer therapy. Hopefully, all of these developments will lead to more patient-specific and targeted anticancer therapies.

Author Contributions: Conceptualization, D.B., K.K.B. and B.R.; methodology, K.K.B., B.R., T.S., and S.P.; formal analysis, K.K.B., B.R., T.S., B.K.C. and D.B.; investigation S.P., T.S., K.K.B. and L.I.A.; writing-original draft preparation, K.K.B., B.R., T.S., S.P., B.K.C., D.B., Z.A.K., H.A.E. writingreview and editing, K.K.B., B.R., T.S., S.P., B.K.C., D.B. and L.I.A. All authors have read and agreed to the published version of the manuscript.

Funding: This work was supported in part by a research grant from the University Grants Commission (NFST) vide Grant No. F1-17.1/2015-16/NFST-2015-17-ST-ASS-3863.

Institutional Review Board Statement: Not applicable.

Informed Consent Statement: Not applicable.

Data Availability Statement: The study did not report any data.

Conflicts of Interest: The authors declare no conflict of interest.

\section{References}

1. Vijayakumar, M.R.; Kosuru, R.; Singh, S.K.; Prasad, C.B.; Narayan, G.; Muthu, M.S.; Singh, S. Resveratrol loaded PLGA:d- $\alpha-$ tocopheryl polyethylene glycol 1000 succinate blend nanoparticles for brain cancer therapy. RSC Adv. 2016, 6, 74254-74268. [CrossRef]

2. Cadinoiu, A.N.; Rata, D.M.; Atanase, L.I.; Mihai, C.T.; Bacaita, S.E.; Popa, M. Formulations Based on Drug Loaded AptamerConjugated Liposomes as a Viable Strategy for the Topical Treatment of Basal Cell Carcinoma-In Vitro Tests. Pharmaceutics 2021, 13, 886. [CrossRef]

3. Saenz del Burgo, L.; Hernández, R.M.; Orive, G.; Pedraz, J.L. Nanotherapeutic approaches for brain cancer management. Nanomedicine 2014, 10, 905-919. [CrossRef]

4. Dolecek, T.A.; Propp, J.M.; Stroup, N.E.; Kruchko, C. CBTRUS statistical report: Primary brain and central nervous system tumors diagnosed in the United States in 2005-2009. Neuro-Oncology 2012, 14 (Suppl. 5), v1-v49. [CrossRef]

5. Cheng, Y.; Morshed, R.A.; Auffinger, B.; Tobias, A.L.; Lesniak, M.S. Multifunctional nanoparticles for brain tumor imaging and therapy. Adv. Drug Deliv. Rev. 2014, 66, 42-57. [CrossRef] 
6. Ostrom, Q.T.; Gittleman, H.; Farah, P.; Ondracek, A.; Chen, Y.; Wolinsky, Y.; Stroup, N.E.; Kruchko, C.; Barnholtz-Sloan, J.S. CBTRUS statistical report: Primary brain and central nervous system tumors diagnosed in the United States in $2006-2010$. Neuro-Oncol. 2013, 15 (Suppl. 2), ii1-ii56. [CrossRef] [PubMed]

7. Atanase, L.I. Micellar Drug Delivery Systems Based on Natural Biopolymers. Polymers 2021, 13, 447. [CrossRef]

8. Sona, M.M.; Viswanadh, M.K.; Singh, R.P.; Agrawal, P.; Mehata, A.K.; Pawde, D.M.; Narendra; Sonkar, R.; Muthu, M.S. Nanotheranostics: Emerging Strategies for Early Diagnosis and Therapy of Brain Cancer. Nanotheranostics 2018, 2, 70-86. [CrossRef]

9. Lapointe, S.; Perry, A.; Butowski, N.A. Primary brain tumours in adults. Lancet 2018, 392, 432-446. [CrossRef]

10. Stawicki, B.; Schacher, T.; Cho, H. Nanogels as a Versatile Drug Delivery System for Brain Cancer. Gels 2021, 7, 63. [CrossRef] [PubMed]

11. Mahmoud, B.S.; AlAmri, A.H.; McConville, C. Polymeric Nanoparticles for the Treatment of Malignant Gliomas. Cancers 2020, $12,175$. [CrossRef] [PubMed]

12. Cerna, T.; Stiborova, M.; Adam, V.; Kizek, R.; Eckschlager, T. Nanocarrier drugs in the treatment of brain tumors. J. Cancer Metastasis Treat. 2016, 2, 407-416. [CrossRef]

13. Kabitha, K.; Rajan, M.S.; Hegde, K.; Koshy, S.; Shenoy, A. A comprehensive review on brain tumor. Int. J. Pharm. Chem. Biol. Sci. 2013, 3, 1165-1171.

14. ELAmrawy, F.; Othman, A.A.; Adkins, C.; Helmy, A.; Nounou, M.I. Tailored nanocarriers and bioconjugates for combating glioblastoma and other brain tumors. J. Cancer Metastasis Treat. 2016, 2, 112-122. [CrossRef]

15. Louis, D.N.; Perry, A.; Wesseling, P.; Brat, D.J.; Cree, I.A.; Figarella-Branger, D.; Hawkins, C.; Ng, H.K.; Pfister, S.M.; Reifenberger, G.; et al. The 2021 WHO Classification of Tumors of the Central Nervous System: A summary. Neuro-Oncol. 2021, 23, 1231-1251. [CrossRef]

16. Paw, I.; Carpenter, R.C.; Watabe, K.; Debinski, W.; Lo, H.-W. Mechanisms regulating glioma invasion. Cancer Lett. 2015, 362, 1-7. [CrossRef] [PubMed]

17. Glaser, T.; Han, I.; Wu, L.; Zeng, X. Targeted Nanotechnology in Glioblastoma Multiforme. Front. Pharmacol. 2017, 8, 166. [CrossRef]

18. Taiarol, L.; Formicola, B.; Magro, R.D.; Sesana, S.; Re, F. An update of nanoparticle-based approaches for glioblastoma multiforme immunotherapy. Nanomedicine 2020, 15, 1861-1871. [CrossRef]

19. Scheithauer, B.W. Development of the WHO classification of tumors of the central nervous system: A historical perspective. Brain Pathol. 2009, 19, 551-564. [CrossRef] [PubMed]

20. Ozdemir-Kaynak, E.; Qutub, A.A.; Yesil-Celiktas, O. Advances in Glioblastoma Multiforme Treatment: New Models for Nanoparticle Therapy. Front. Physiol. 2018, 9, 170. [CrossRef]

21. Alifieris, C.; Trafalis, D.T. Glioblastoma multiforme: Pathogenesis and treatment. Pharmacol. Ther. 2015, 152, 63-82. [CrossRef]

22. van den Bent, M.J.; Afra, D.; de Witte, O.; Ben Hassel, M.; Schraub, S.; Hoang-Xuan, K.; Malmström, P.-O.; Collette, L.; Piérart, M.; Mirimanoff, R.; et al. Long-term efficacy of early versus delayed radiotherapy for low-grade astrocytoma and oligodendroglioma in adults: The EORTC 22845 randomised trial. Lancet 2005, 366, 985-990. [CrossRef]

23. Beier, D.; Schulz, J.B.; Beier, C.P. Chemoresistance of glioblastoma cancer stem cells-Much more complex than expected. Mol. Cancer 2011, 10, 128. [CrossRef] [PubMed]

24. Cook, L.; Freedman, J. Brain Tumors; The Rosen Publishing Group: New York, NY, USA, 2012.

25. Kim, S.-S.; Harford, J.B.; Pirollo, K.F.; Chang, E.H. Effective treatment of glioblastoma requires crossing the blood-brain barrier and targeting tumors including cancer stem cells: The promise of nanomedicine. Biochem. Biophys. Res. Commun. 2015, 468, 485-489. [CrossRef]

26. Binello, E.; Germano, I.M. Targeting glioma stem cells: A novel framework for brain tumors. Cancer Sci. 2011, 102, 1958-1966. [CrossRef]

27. Muthu, M.S.; Mei, L.; Feng, S.-S. Nanotheranostics: Advanced nanomedicine for the integration of diagnosis and therapy. Nanomedicine 2014, 9, 1277-1280. [CrossRef] [PubMed]

28. Jain, K.K. Nanobiotechnology-based strategies for crossing the blood-brain barrier. Nanomedicine 2012, 7, 1225-1233. [CrossRef] [PubMed]

29. Mohanta, B.C.; Palei, N.N.; Surendran, V.; Dinda, S.C.; Rajangam, J.; Deb, J.; Sahoo, B.M. Lipid Based Nanoparticles: Current Strategies for Brain Tumor Targeting. Curr. Nanomater. 2019, 4, 84-100. [CrossRef]

30. Dinda, S.C.; Pattnaik, G. Nanobiotechnology-based drug delivery in brain targeting. Curr. Pharm. Biotechnol. 2013, 14, 1264-1274. [CrossRef] [PubMed]

31. Zhang, W.; Mehta, A.; Tong, Z.; Esser, L.; Voelcker, N.H. Development of Polymeric Nanoparticles for Blood-Brain Barrier Transfer-Strategies and Challenges. Adv. Sci. 2021, 8, 2003937. [CrossRef]

32. Serlin, Y.; Shelef, I.; Knyazer, B.; Friedman, A. Anatomy and physiology of the blood-brain barrier. Semin. Cell Dev. Biol. 2015, 38, 2-6. [CrossRef]

33. Pardridge, W.M. The blood-brain barrier: Bottleneck in brain drug development. NeuroRx 2005, 2, 3-14. [CrossRef]

34. Jena, L.; McErlean, E.; McCarthy, H. Delivery across the blood-brain barrier: Nanomedicine for glioblastoma multiforme. Drug Deliv. Transl. Res. 2020, 10, 304-318. [CrossRef] [PubMed] 
35. Ising, C.; Heneka, M.T. Functional and structural damage of neurons by innate immune mechanisms during neurodegeneration. Cell Death Dis. 2018, 9, 120. [CrossRef]

36. Bhowmik, A.; Khan, R.; Ghosh, M.K. Blood brain barrier: A challenge for effectual therapy of brain tumors. BioMed Res. Int. 2015, 2015, 320941. [CrossRef]

37. Stephenson, J.; Nutma, E.; van der Valk, P.; Amor, S. Inflammation in CNS neurodegenerative diseases. Immunology 2018, 154, 204-219. [CrossRef]

38. Belykh, E.; Shaffer, K.V.; Lin, C.; Byvaltsev, V.A.; Preul, M.C.; Chen, L. Blood-Brain Barrier, Blood-Brain Tumor Barrier, and Fluorescence-Guided Neurosurgical Oncology: Delivering Optical Labels to Brain Tumors. Front. Oncol. 2020, 10, 739. [CrossRef]

39. Reddy, S.; Tatiparti, K.; Sau, S.; Iyer, A.K. Recent advances in nano delivery systems for blood-brain barrier (BBB) penetration and targeting of brain tumors. Drug Discov. Today 2021, 26, 1944-1952. [CrossRef] [PubMed]

40. Wei, X.; Chen, X.; Ying, M.; Lu, W. Brain tumor-targeted drug delivery strategies. Acta Pharm. Sin. B 2014, 4, 193-201. [CrossRef] [PubMed]

41. Latasha, L.P. Nanomedicines and the future of glioma. Neuro. Oncol. 2015, 10, 16-22.

42. Pati, S.; Chatterji, A.; Dash, B.P.; Nelson, B.R.; Sarkar, T.; Shahimi, S.; Edinur, H.A.; Abd Manan, T.S.B.; Jena, P.; Mohanta, Y.K.; et al. Structural characterization and antioxidant potential of chitosan by $\gamma$-irradiation from the carapace of horseshoe crab. Polymers 2020, 12, 2361. [CrossRef] [PubMed]

43. Pati, S.; Sarkar, T.; Sheikh, H.I.; Bharadwaj, K.K.; Mohapatra, P.K.; Chatterji, A.; Dash, B.P.; Edinur, H.A.; Nelson, B.R. $\gamma$-Irradiated Chitosan from Carcinoscorpius rotundicauda (Latreille, 1802) Improves the Shelf Life of Refrigerated Aquatic Products. Front. Mar. Sci. 2021, 8, 498. [CrossRef]

44. Rabha, B.; Bharadwaj, K.K.; Baishya, D.; Sarkar, T.; Edinur, H.A.; Pati, S. Synthesis and Characterization of Diosgenin Encapsulated Poly-E-Caprolactone-Pluronic Nanoparticles and Its Effect on Brain Cancer Cells. Polymers 2021, 13, 1322. [CrossRef]

45. Lo, Y.-L.; Lin, H.-C.; Hong, S.-T.; Chang, C.-H.; Wang, C.-S.; Lin, A.M.-Y. Lipid polymeric nanoparticles modified with tight junction-modulating peptides promote afatinib delivery across a blood-brain barrier model. Cancer Nanotechnol. 2021, 12, 13. [CrossRef]

46. Kou, L.; Hou, Y.; Yao, Q.; Guo, W.; Wang, G.; Wang, M.; Fu, Q.; He, Z.; Ganapathy, V.; Sun, J. L-Carnitine-conjugated nanoparticles to promote permeation across blood-brain barrier and to target glioma cells for drug delivery via the novel organic cation/carnitine transporter OCTN2. Artif. Cells Nanomed. Biotechnol. 2018, 46, 1605-1616. [CrossRef] [PubMed]

47. Li, H.; Tong, Y.; Bai, L.; Ye, L.; Zhong, L.; Duan, X.; Zhu, Y. Lactoferrin functionalized PEG-PLGA nanoparticles of shikonin for brain targeting therapy of glioma. Int. J. Biol. Macromol. 2018, 107, 204-211. [CrossRef]

48. Golombek, S.K.; May, J.-N.; Theek, B.; Appold, L.; Drude, N.; Kiessling, F.; Lammers, T. Tumor targeting via EPR: Strategies to enhance patient responses. Adv. Drug Deliv. Rev. 2018, 130, 17-38. [CrossRef]

49. Patel, T.; Zhou, J.; Piepmeier, J.M.; Saltzman, W.M. Polymeric nanoparticles for drug delivery to the central nervous system. Adv. Drug Deliv. Rev. 2012, 64, 701-705. [CrossRef]

50. Pulgar, V.M. Transcytosis to Cross the Blood Brain Barrier, New Advancements and Challenges. Front. Neurosci. 2018, 12, 1019. [CrossRef] [PubMed]

51. Kou, L.; Bhutia, Y.D.; Yao, Q.; He, Z.; Sun, J.; Ganapathy, V. Transporter-Guided Delivery of Nanoparticles to Improve Drug Permeation across Cellular Barriers and Drug Exposure to Selective Cell Types. Front. Pharmacol. 2018, 9, 27. [CrossRef]

52. Zhi, K.; Raji, B.; Nookala, A.R.; Khan, M.M.; Nguyen, X.H.; Sakshi, S.; Pourmotabbed, T.; Yallapu, M.M.; Kochat, H.; Tadrous, E.; et al. PLGA Nanoparticle-Based Formulations to Cross the Blood-Brain Barrier for Drug Delivery: From R\&D to cGMP. Pharmaceutics 2021, 13, 500. [CrossRef]

53. Lu, W.; Zhang, Y.; Tan, Y.-Z.; Hu, K.-L.; Jiang, X.-G.; Fu, S.-K. Cationic albumin-conjugated pegylated nanoparticles as novel drug carrier for brain delivery. J. Control. Release 2005, 107, 428-448. [CrossRef]

54. Jiang, X.; Xin, H.; Ren, Q.; Gu, J.; Zhu, L.; Du, F.; Feng, C.; Xie, Y.; Sha, X.; Fang, X. Nanoparticles of 2-deoxy-d-glucose functionalized poly(ethylene glycol)-co-poly(trimethylene carbonate) for dual-targeted drug delivery in glioma treatment. Biomaterials 2014, 35, 518-529. [CrossRef]

55. Bray, N. Biologics: Transferrin' bispecific antibodies across the blood-brain barrier. Nat. Rev. Drug Discov. 2015, 14, 14-15. [CrossRef]

56. Cui, Y.; Xu, Q.; Chow, P.K.-H.; Wang, D.; Wang, C.-H. Transferrin-conjugated magnetic silica PLGA nanoparticles loaded with doxorubicin and paclitaxel for brain glioma treatment. Biomaterials 2013, 34, 8511-8520. [CrossRef]

57. Wang, Z.H.; Wang, Z.Y.; Sun, C.S.; Wang, C.Y.; Jiang, T.Y.; Wang, S.L. Trimethylated chitosan-conjugated PLGA nanoparticles for the delivery of drugs $\mathrm{t}$ the brain. Biomaterials 2010, 31, 908-915. [CrossRef]

58. Wang, L.; Hao, Y.; Li, H.; Zhao, Y.; Meng, D.; Li, D.; Shi, J.; Zhang, H.; Zhang, Z.; Zhang, Y. Co-delivery of doxorubicin and siRNA for glioma therapy by a brain targeting system: Angiopep-2-modified poly(lactic-co-glycolic acid) nanoparticles. J. Drug Target. 2015, 23, 832-846. [CrossRef] [PubMed]

59. Kuo, Y.-C.; Chen, Y.-C. Targeting delivery of etoposide to inhibit the growth of human glioblastoma multiforme using lactoferrinand folic acid-grafted poly(lactide-co-glycolide) nanoparticles. Int. J. Pharm. 2015, 479, 138-149. [CrossRef] [PubMed]

60. Hua, H.; Zhang, X.; Mu, H.; Meng, Q.; Jiang, Y.; Wang, Y.; Lu, X.; Wang, A.; Liu, S.; Zhang, Y.; et al. RVG29-modified docetaxel-loaded nanoparticles for brain-targeted glioma therapy. Int. J. Pharm. 2018, 543, 179-189. [CrossRef] 
61. Ramalho, M.J.; Sevin, E.; Gosselet, F.; Lima, J.; Coelho, M.A.N.; Loureiro, J.A.; Pereira, M.C. Receptor-mediated PLGA nanoparticles for glioblastoma multiforme treatment. Int. J. Pharm. 2018, 545, 84-92. [CrossRef] [PubMed]

62. Cui, Y.; Zhang, M.; Zeng, F.; Jin, H.; Xu, Q.; Huang, Y. Dual-Targeting Magnetic PLGA Nanoparticles for Codelivery of Paclitaxel and Curcumin for Brain Tumor Therapy. ACS Appl. Mater. Interfaces 2016, 8, 32159-32169. [CrossRef]

63. Xin, H.; Sha, X.; Jiang, X.; Zhang, W.; Chen, L.; Fang, X. Anti-glioblastoma efficacy and safety of paclitaxel-loading Angiopepconjugated dual targeting PEG-PCL nanoparticles. Biomaterials 2012, 33, 8167-8176. [CrossRef]

64. Muniswamy, V.J.; Raval, N.; Gondaliya, P.; Tambe, V.; Kalia, K.; Tekade, R.K. 'Dendrimer-Cationized-Albumin' encrusted polymeric nanoparticle improves BBB penetration and anticancer activity of doxorubicin. Int. J. Pharm. 2019, 555, 77-99. [CrossRef]

65. Zhu, Y.; Zhang, J.; Meng, F.; Deng, C.; Cheng, R.; Feijen, J.; Zhong, Z. cRGD-functionalized reduction-sensitive shell-sheddable biodegradable micelles mediate enhanced doxorubicin delivery to human glioma xenografts in vivo. J. Control. Release 2016, 233, 29-38. [CrossRef] [PubMed]

66. Chen, W.; Zou, Y.; Zhong, Z.; Haag, R. Cyclo(RGD)-Decorated Reduction-Responsive Nanogels Mediate Targeted Chemotherapy of Integrin Overexpressing Human Glioblastoma In Vivo. Small 2017, 13, 1601997. [CrossRef] [PubMed]

67. Bi, Y.; Liu, L.; Lu, Y.; Sun, T.; Shen, C.; Chen, X.; Chen, Q.; An, S.; He, X.; Ruan, C.; et al. T7 Peptide-Functionalized PEG-PLGA Micelles Loaded with Carmustine for Targeting Therapy of Glioma. ACS Appl. Mater. Interfaces 2016, 8, 27465-27473. [CrossRef]

68. Bhowmik, A.; Chakravarti, S.; Ghosh, A.; Shaw, R.; Bhandary, S.; Bhattacharyya, S.; Sen, P.C.; Ghosh, M.K. Anti-SSTR2 peptide based targeted delivery of potent PLGA encapsulated 3,3'-diindolylmethane nanoparticles through blood brain barrier prevents glioma progression. Oncotarget 2017, 8, 65339-65358. [CrossRef]

69. Prabhu, R.H.; Patravale, V.B.; Joshi, M.D. Polymeric nanoparticles for targeted treatment in oncology: Current insights. Int. J. Nanomed. 2015, 10, 1001-1018. [CrossRef]

70. von Roemeling, C.; Jiang, W.; Chan, C.K.; Weissman, I.L.; Kim, B.Y.S. Breaking Down the Barriers to Precision Cancer Nanomedicine. Trends Biotechnol. 2017, 35, 159-171. [CrossRef]

71. Zielińska, A.; Carreiró, F.; Oliveira, A.M.; Neves, A.; Pires, B.; Venkatesh, D.N.; Durazzo, A.; Lucarini, M.; Eder, P.; Silva, A.M.; et al. Polymeric Nanoparticles: Production, Characterization, Toxicology and Ecotoxicology. Molecules 2020, 25, 3731. [CrossRef] [PubMed]

72. Guzmán, E.; Mateos-Maroto, A.; Ruano, M.; Ortega, F.; Rubio, R.G. Layer-by-Layer polyelectrolyte assemblies for encapsulation and release of active compounds. Adv. Colloid Interface Sci. 2017, 249, 290-307. [CrossRef] [PubMed]

73. Mateos-Maroto, A.; Abelenda-Núñez, I.; Ortega, F.; Rubio, R.G.; Guzmán, E. Polyelectrolyte Multilayers on Soft Colloidal Nanosurfaces: A New Life for the Layer-By-Layer Method. Polymer 2021, 13, 1221. [CrossRef]

74. Peer, D.; Karp, J.M.; Hong, S.; Farokhzad, O.C.; Margalit, R.; Langer, R. Nanocarriers as an emerging platform for cancer therapy. Nat. Nanotechnol. 2007, 2, 751-760. [CrossRef]

75. Varan, C.; Bilensoy, E. Cationic PEGylated polycaprolactone nanoparticles carrying post-operation docetaxel for glioma treatment. Beilstein J. Nanotechnol. 2017, 8, 1446-1456. [CrossRef] [PubMed]

76. Pinto, M.P.; Arce, M.; Yameen, B.; Vilos, C. Targeted brain delivery nanoparticles for malignant gliomas. Nanomedicine 2017, 12, 59-72. [CrossRef]

77. Gaudin, A.; Song, E.; King, A.R.; Saucier-Sawyer, J.K.; Bindra, R.; Desmaële, D.; Couvreur, P.; Saltzman, W.M. PEGylated squalenoyl-gemcitabine nanoparticles for the treatment of glioblastoma. Biomaterials 2016, 105, 136-144. [CrossRef] [PubMed]

78. Yang, J.; Li, Y.; Zhang, T.; Zhang, X. Development of bioactive materials for glioblastoma therapy. Bioact. Mater. 2016, 1, 29-38. [CrossRef]

79. Zhong, Y.; Meng, F.; Deng, C.; Zhong, Z. Ligand-Directed Active Tumor-Targeting Polymeric Nanoparticles for Cancer Chemotherapy. Biomacromolecules 2014, 15, 1955-1969. [CrossRef]

80. Sun, P.; Xiao, Y.; Di, Q.; Ma, W.; Ma, X.; Wang, Q.; Chen, W. Transferrin Receptor-Targeted PEG-PLA Polymeric Micelles for Chemotherapy Against Glioblastoma Multiforme. Int. J. Nanomed. 2020, 15, 6673-6688. [CrossRef]

81. Wen, G.; Li, X.; Zhang, Y.; Han, X.; Xu, X.; Liu, C.; Chan, K.W.Y.; Lee, C.-S.; Yin, C.; Bian, L.; et al. Effective Phototheranostics of Brain Tumor Assisted by Near-Infrared-II Light-Responsive Semiconducting Polymer Nanoparticles. ACS Appl. Mater. Interfaces 2020, 12, 33492-33499. [CrossRef]

82. Ibarra, L.E.; Beaugé, L.; Arias-Ramos, N.; Rivarola, V.A.; Chesta, C.A.; López-Larrubia, P.; Palacios, R.E. Trojan horse monocytemediated delivery of conjugated polymer nanoparticles for improved photodynamic therapy of glioblastoma. Nanomedicine 2020, 15, 1687-1707. [CrossRef] [PubMed]

83. Gregory, J.V.; Kadiyala, P.; Doherty, R.; Cadena, M.; Habeel, S.; Ruoslahti, E.; Lowenstein, P.R.; Castro, M.G.; Lahann, J. Systemic brain tumor delivery of synthetic protein nanoparticles for glioblastoma therapy. Nat. Commun. 2020, 11, 5687. [CrossRef]

84. Caverzán, M.D.; Beaugé, L.; Chesta, C.A.; Palacios, R.E.; Ibarra, L.E. Photodynamic therapy of Glioblastoma cells using doped conjugated polymer nanoparticles: An in vitro comparative study based on redox status. J. Photochem. Photobiol. B Biol. 2020, 212, 112045. [CrossRef] [PubMed]

85. Zhou, J.; Patel, T.R.; Sirianni, R.W.; Strohbehn, G.; Zheng, M.-Q.; Duong, N.; Schafbauer, T.; Huttner, A.J.; Huang, Y.; Carson, R.E.; et al. Highly penetrative, drug-loaded nanocarriers improve treatment of glioblastoma. Proc. Natl. Acad. Sci. USA 2013, 110, 11751-11756. [CrossRef] 
86. Guerrero-Cázares, H.; Tzeng, S.Y.; Young, N.P.; Abutaleb, A.O.; Quiñones-Hinojosa, A.; Green, J.J. Biodegradable Polymeric Nanoparticles Show High Efficacy and Specificity at DNA Delivery to Human Glioblastoma in Vitro and in Vivo. ACS Nano 2014, 8, 5141-5153. [CrossRef]

87. Choi, J.; Yang, J.; Park, J.; Kim, E.; Suh, J.-S.; Huh, Y.-M.; Haam, S. Specific Near-IR Absorption Imaging of Glioblastomas Using Integrin-Targeting Gold Nanorods. Adv. Funct. Mater. 2011, 21, 1082-1088. [CrossRef]

88. Oli, M. Aptamer conjugated gold nanorods for targeted nanothermal radiation of Glioblastoma cancer cells (A novel selective targeted approach to cancer treatment). Young Sci. J. 2009, 2, 18. [CrossRef]

89. Hoare, T.; Santamaria, J.; Goya, G.F.; Irusta, S.; Lin, D.; Lau, S.; Padera, R.; Langer, R.; Kohane, D.S. A Magnetically Triggered Composite Membrane for On-Demand Drug Delivery. Nano Lett. 2009, 9, 3651-3657. [CrossRef]

90. Kim, J.; Mondal, S.K.; Tzeng, S.Y.; Rui, Y.; Al-kharboosh, R.; Kozielski, K.K.; Bhargav, A.G.; Garcia, C.A.; Quiñones-Hinojosa, A.; Green, J.J. Poly(ethylene glycol)-Poly(beta-amino ester)-Based Nanoparticles for Suicide Gene Therapy Enhance Brain Penetration and Extend Survival in a Preclinical Human Glioblastoma Orthotopic Xenograft Model. ACS Biomater. Sci. Eng. 2020, 6, $2943-2955$. [CrossRef]

91. Lu, Q.; Cai, X.; Zhang, X.; Li, S.; Song, Y.; Du, D.; Dutta, P.; Lin, Y. Synthetic Polymer Nanoparticles Functionalized with Different Ligands for Receptor-mediated Transcytosis across Blood-Brain Barrier. ACS Appl. Bio Mater. 2018, 1, 1687-1694. [CrossRef]

92. Hu, Q.; Gao, X.; Gu, G.; Kang, T.; Tu, Y.; Liu, Z.; Song, Q.; Yao, L.; Pang, Z.; Jiang, X.; et al. Glioma therapy using tumor homing and penetrating peptide-functionalized PEG-PLA nanoparticles loaded with paclitaxel. Biomaterials 2013, 34, 5640-5650 [CrossRef]

93. Guo, W.; Li, A.; Jia, Z.; Yuan, Y.; Dai, H.; Li, H. Transferrin modified PEG-PLA-resveratrol conjugates: In vitro and in vivo studies for glioma. Eur. J. Pharmacol. 2013, 718, 41-47. [CrossRef]

94. Ambruosi, A.; Khalansky, A.S.; Yamamoto, H.; Gelperina, S.E.; Begley, D.J.; Kreuter, J. Biodistribution of polysorbate 80-coated doxorubicin-loaded [14C]-poly(butyl cyanoacrylate) nanoparticles after intravenous administration to glioblastoma-bearing rats. J. Drug Target. 2006, 14, 97-105. [CrossRef]

95. Mahmoud, B.S.; McConville, C. Development and Optimization of Irinotecan-Loaded PCL Nanoparticles and Their Cytotoxicity against Primary High-Grade Glioma Cells. Pharmaceutics 2021, 13, 541. [CrossRef]

96. Zhong, Y.; Wang, C.; Cheng, R.; Cheng, L.; Meng, F.; Liu, Z.; Zhong, Z. cRGD-directed, NIR-responsive and robust AuNR/PEGPCL hybrid nanoparticles for targeted chemotherapy of glioblastoma in vivo. J. Control. Release 2014, 195, 63-71. [CrossRef] [PubMed]

97. Irani, M.; Sadeghi, G.M.M.; Haririan, I. The sustained delivery of temozolomide from electrospun PCL-Diol-b-PU/gold nanocompsite nanofibers to treat glioblastoma tumors. Mater. Sci. Eng. C. Mater. Biol. Appl. 2017, 75, 165-174. [CrossRef]

98. Gu, G.; Xia, H.; Hu, Q.; Liu, Z.; Jiang, M.; Kang, T.; Miao, D.; Tu, Y.; Pang, Z.; Song, Q.; et al. PEG-co-PCL nanoparticles modified with MMP-2/9 activatable low molecular weight protamine for enhanced targeted glioblastoma therapy. Biomaterials 2013, 34, 196-208. [CrossRef]

99. Yan, H.; Wang, J.; Yi, P.; Lei, H.; Zhan, C.; Xie, C.; Feng, L.; Qian, J.; Zhu, J.; Lu, W.; et al. Imaging brain tumor by dendrimer-based optical/paramagnetic nanoprobe across the blood-brain barrier. Chem. Commun. 2011, 47, 8130-8132. [CrossRef] [PubMed]

100. Alizadeh, D.; Zhang, L.; Hwang, J.; Schluep, T.; Badie, B. Tumor-associated macrophages are predominant carriers of cyclodextrinbased nanoparticles into gliomas. Nanomedicine 2010, 6, 382-390. [CrossRef] [PubMed]

101. Sharma, S.; Chockalingam, S.; Sanpui, P.; Chattopadhyay, A.; Ghosh, S.S. Silver nanoparticles impregnated alginate-chitosanblended nanocarrier induces apoptosis in human glioblastoma cells. Adv. Healthc. Mater. 2014, 3, 106-114. [CrossRef] [PubMed]

102. Cohen, Z.R.; Ramishetti, S.; Peshes-Yaloz, N.; Goldsmith, M.; Wohl, A.; Zibly, Z.; Peer, D. Localized RNAi Therapeutics of Chemoresistant Grade IV Glioma Using Hyaluronan-Grafted Lipid-Based Nanoparticles. ACS Nano 2015, 9, 1581-1591. [CrossRef]

103. Nejat, H.; Rabiee, M.; Varshochian, R.; Tahriri, M.; Jazayeri, H.E.; Rajadas, J.; Ye, H.; Cui, Z.; Tayebi, L. Preparation and characterization of cardamom extract-loaded gelatin nanoparticles as effective targeted drug delivery system to treat glioblastoma. React. Funct. Polym. 2017, 120, 46-56. [CrossRef]

104. Deng, G.; Peng, X.; Sun, Z.; Zheng, W.; Yu, J.; Du, L.; Chen, H.; Gong, P.; Zhang, P.; Cai, L.; et al. Natural-Killer-Cell-Inspired Nanorobots with Aggregation-Induced Emission Characteristics for Near-Infrared-II Fluorescence-Guided Glioma Theranostics. ACS Nano 2020, 14, 11452-11462. [CrossRef]

105. Wang, J.; Yang, Y.; Zhang, Y.; Huang, M.; Zhou, Z.; Luo, W.; Tang, J.; Wang, J.; Xiao, Q.; Chen, H.; et al. Dual-Targeting HeparinBased Nanoparticles that Re-Assemble in Blood for Glioma Therapy through Both Anti-Proliferation and Anti-Angiogenesis. Adv. Funct. Mater. 2016, 26, 7873-7885. [CrossRef]

106. Gholami, L.; Tafaghodi, M.; Abbasi, B.; Daroudi, M.; Kazemi Oskuee, R. Preparation of superparamagnetic iron oxide/doxorubicin loaded chitosan nanoparticles as a promising glioblastoma theranostic tool. J. Cell. Physiol. 2019, 234, 1547-1559. [CrossRef] [PubMed]

107. Ruan, C.; Liu, L.; Lu, Y.; Zhang, Y.; He, X.; Chen, X.; Zhang, Y.; Chen, Q.; Guo, Q.; Sun, T.; et al. Substance P-modified human serum albumin nanoparticles loaded with paclitaxel for targeted therapy of glioma. Acta Pharm. Sin. B 2018, 8, 85-96. [CrossRef] [PubMed]

108. Byeon, H.J.; Thao, L.Q.; Lee, S.; Min, S.Y.; Lee, E.S.; Shin, B.S.; Choi, H.-G.; Youn, Y.S. Doxorubicin-loaded nanoparticles consisted of cationic- and mannose-modified-albumins for dual-targeting in brain tumors. J. Control. Release 2016, 225, 301-313. [CrossRef] 
109. Lin, T.; Zhao, P.; Jiang, Y.; Tang, Y.; Jin, H.; Pan, Z.; He, H.; Yang, V.C.; Huang, Y. Blood-Brain-Barrier-Penetrating Albumin Nanoparticles for Biomimetic Drug Delivery via Albumin-Binding Protein Pathways for Antiglioma Therapy. ACS Nano 2016, 10, 9999-10012. [CrossRef]

110. Gao, C.; Liang, J.; Zhu, Y.; Ling, C.; Cheng, Z.; Li, R.; Qin, J.; Lu, W.; Wang, J. Menthol-modified casein nanoparticles loading 10-hydroxycamptothecin for glioma targeting therapy. Acta Pharm. Sin. B 2019, 9, 843-857. [CrossRef]

111. Lam, F.C.; Morton, S.W.; Wyckoff, J.; Vu Han, T.-L.; Hwang, M.K.; Maffa, A.; Balkanska-Sinclair, E.; Yaffe, M.B.; Floyd, S.R.; Hammond, P.T. Enhanced efficacy of combined temozolomide and bromodomain inhibitor therapy for gliomas using targeted nanoparticles. Nat. Commun. 2018, 9, 1991. [CrossRef]

112. Kuhnline Sloan, C.D.; Nandi, P.; Linz, T.H.; Aldrich, J.V.; Audus, K.L.; Lunte, S.M. Analytical and biological methods for probing the blood-brain barrier. Annu. Rev. Anal. Chem. 2012, 5, 505-531. [CrossRef] [PubMed]

113. Carlsson, S.K.; Brothers, S.P.; Wahlestedt, C. Emerging treatment strategies for glioblastoma multiforme. EMBO Mol. Med. 2014, 6, 1359-1370. [CrossRef] [PubMed]

114. Vasefi, F.; MacKinnon, N.; Farkas, D.L.; Kateb, B. Review of the potential of optical technologies for cancer diagnosis in neurosurgery: A step toward intraoperative neurophotonics. Neurophotonics 2017, 4, 11010. [CrossRef] [PubMed]

115. Fakhoury, M. Drug delivery approaches for the treatment of glioblastoma multiforme. Artif. Cells Nanomed. Biotechnol. 2016, 44, 1365-1373. [CrossRef]

116. Dhermain, F.G.; Hau, P.; Lanfermann, H.; Jacobs, A.H.; van den Bent, M.J. Advanced MRI and PET imaging for assessment of treatment response in patients with gliomas. Lancet. Neurol. 2010, 9, 906-920. [CrossRef]

117. Galldiks, N.; Dunkl, V.; Kracht, L.W.; Vollmar, S.; Jacobs, A.H.; Fink, G.R.; Schroeter, M. Volumetry of [ $\left.{ }^{11} \mathrm{C}\right]-$ methionine positron emission tomographic uptake as a prognostic marker before treatment of patients with malignant glioma. Mol. Imaging 2012, 11, 516-527. [CrossRef]

118. Zottel, A.; Videtič Paska, A.; Jovčevska, I. Nanotechnology Meets Oncology: Nanomaterials in Brain Cancer Research, Diagnosis and Therapy. Materials 2019, 12, 1588. [CrossRef] [PubMed]

119. d'Angelo, M.; Castelli, V.; Benedetti, E.; Antonosante, A.; Catanesi, M.; Dominguez-Benot, R.; Pitari, G.; Ippoliti, R.; Cimini, A. Theranostic Nanomedicine for Malignant Gliomas. Front. Bioeng. Biotechnol. 2019, 7, 325. [CrossRef]

120. Tang, W.; Fan, W.; Lau, J.; Deng, L.; Shen, Z.; Chen, X. Emerging blood-brain-barrier-crossing nanotechnology for brain cancer theranostics. Chem. Soc. Rev. 2019, 48, 2967-3014. [CrossRef]

121. Reddy, L.H.; Couvreur, P. Nanotechnology for therapy and imaging of liver diseases. J. Hepatol. 2011, 55, 1461-1466. [CrossRef]

122. Gauger, A.J.; Hershberger, K.K.; Bronstein, L.M. Theranostics Based on Magnetic Nanoparticles and Polymers: Intelligent Design for Efficient Diagnostics and Therapy. Front. Chem. 2020, 8, 561. [CrossRef]

123. van Vlerken, L.E.; Amiji, M.M. Multi-functional polymeric nanoparticles for tumour-targeted drug delivery. Expert Opin. Drug Deliv. 2006, 3, 205-216. [CrossRef]

124. Qu, J.; Zhang, L.; Chen, Z.; Mao, G.; Gao, Z.; Lai, X.; Zhu, X.; Zhu, J. Nanostructured lipid carriers, solid lipid nanoparticles, and polymeric nanoparticles: Which kind of drug delivery system is better for glioblastoma chemotherapy? Drug Deliv. 2016, 23, 3408-3416. [CrossRef] [PubMed]

125. Luk, B.T.; Zhang, L. Current Advances in Polymer-Based Nanotheranostics for Cancer Treatment and Diagnosis. ACS Appl. Mater. Interfaces 2014, 6, 21859-21873. [CrossRef] [PubMed]

126. Ganipineni, L.P.; Ucakar, B.; Joudiou, N.; Bianco, J.; Danhier, P.; Zhao, M.; Bastiancich, C.; Gallez, B.; Danhier, F.; Préat, V. Magnetic targeting of paclitaxel-loaded poly(lactic-co-glycolic acid)-based nanoparticles for the treatment of glioblastoma. Int. J. Nanomed. 2018, 13, 4509-4521. [CrossRef] [PubMed]

127. Strohbehn, G.; Coman, D.; Han, L.; Ragheb, R.R.T.; Fahmy, T.M.; Huttner, A.J.; Hyder, F.; Piepmeier, J.M.; Saltzman, W.M.; Zhou, J. Imaging the delivery of brain-penetrating PLGA nanoparticles in the brain using magnetic resonance. J. Neurooncol. 2015, 121, 441-449. [CrossRef]

128. Ling, Y.; Wei, K.; Zou, F.; Zhong, S. Temozolomide loaded PLGA-based superparamagnetic nanoparticles for magnetic resonance imaging and treatment of malignant glioma. Int. J. Pharm. 2012, 430, 266-275. [CrossRef]

129. Sun, L.; Joh, D.Y.; Al-Zaki, A.; Stangl, M.; Murty, S.; Davis, J.J.; Baumann, B.C.; Alonso-Basanta, M.; Kaol, G.D.; Tsourkas, A.; et al. Theranostic Application of Mixed Gold and Superparamagnetic Iron Oxide Nanoparticle Micelles in Glioblastoma Multiforme. J. Biomed. Nanotechnol. 2016, 12, 347-356. [CrossRef] [PubMed]

130. Shevtsov, M.; Nikolaev, B.; Marchenko, Y.; Yakovleva, L.; Skvortsov, N.; Mazur, A.; Tolstoy, P.; Ryzhov, V.; Multhoff, G. Targeting experimental orthotopic glioblastoma with chitosan-based superparamagnetic iron oxide nanoparticles (CS-DX-SPIONs). Int. J. Nanomed. 2018, 13, 1471-1482. [CrossRef]

131. Xu, H.-L.; Mao, K.-L.; Huang, Y.-P.; Yang, J.-J.; Xu, J.; Chen, P.-P.; Fan, Z.-L.; Zou, S.; Gao, Z.-Z.; Yin, J.-Y.; et al. Glioma-targeted superparamagnetic iron oxide nanoparticles as drug-carrying vehicles for theranostic effects. Nanoscale 2016, 8, 14222-14236. [CrossRef] [PubMed]

132. Bernal, G.M.; LaRiviere, M.J.; Mansour, N.; Pytel, P.; Cahill, K.E.; Voce, D.J.; Kang, S.; Spretz, R.; Welp, U.; Noriega, S.E.; et al. Convection-enhanced delivery and in vivo imaging of polymeric nanoparticles for the treatment of malignant glioma. Nanomedicine 2014, 10, 149-157. [CrossRef]

133. Mahmoudi, M.; Bertrand, N.; Zope, H.; Farokhzad, O.C. Emerging understanding of the protein corona at the nano-bio interfaces. Nano Today 2016, 11, 817-832. [CrossRef] 
134. Rosenblum, D.; Joshi, N.; Tao, W.; Karp, J.M.; Peer, D. Progress and challenges towards targeted delivery of cancer therapeutics. Nat. Commun. 2018, 9, 1410. [CrossRef]

135. Neerooa, B.N.; Ooi, L.-T.; Shameli, K.; Dahlan, N.A.; Islam, J.M.M.; Pushpamalar, J.; Teow, S.-Y. Development of Polymer-Assisted Nanoparticles and Nanogels for Cancer Therapy: An Update. Gels 2021, 7, 60. [CrossRef] [PubMed]

136. Bharadwaj, K.K.; Rabha, B.; Pati, S.; Sarkar, T.; Choudhury, B.K.; Barman, A.; Bhattacharjya, D.; Srivastava, A.; Baishya, D.; Edinur, H.A.; et al. Green Synthesis of Gold Nanoparticles Using Plant Extracts as Beneficial Prospect for Cancer Theranostics. Molecules 2021, 26, 6389. [CrossRef] [PubMed] 